\title{
Influence of 3d Transition Metal Doping on Lithium Stabilized Na- $\beta^{\prime \prime}$-Alumina Solid Electrolytes
}

\author{
Cornelius L. Dirksen*(D), Karl Skadell, Matthias Schulz ${ }^{\mathbb{D}}$, Micha P. Fertig (D) and Michael Stelter \\ Fraunhofer Institute for Ceramic Technologies and Systems IKTS, Michael-Faraday-Str. 1, 07629 Hermsdorf, \\ Germany; Karl.Skadell@ikts.fraunhofer.de (K.S.); Matthias.Schulz@ikts.fraunhofer.de (M.S.); \\ Micha.Philip.Fertig@ikts.fraunhofer.de (M.P.F.); Michael.Stelter@ikts.fraunhofer.de (M.S.) \\ * Correspondence: Cornelius.Dirksen@ikts.fraunhofer.de
}

check for updates

Citation: Dirksen, C.L.; Skadell, K.; Schulz, M.; Fertig, M.P.; Stelter, M. Influence of $3 \mathrm{~d}$ Transition Metal Doping on Lithium Stabilized $\mathrm{Na}-\beta^{\prime \prime}$-Alumina Solid Electrolytes. Materials 2021, 14, 5389. https:// doi.org/10.3390/ma14185389

Academic Editor: Guosheng Li

Received: 26 August 2021

Accepted: 15 September 2021

Published: 17 September 2021

Publisher's Note: MDPI stays neutral with regard to jurisdictional claims in published maps and institutional affiliations.

Copyright: (c) 2021 by the authors. Licensee MDPI, Basel, Switzerland. This article is an open access article distributed under the terms and conditions of the Creative Commons Attribution (CC BY) license (https:// creativecommons.org/licenses/by/ $4.0 /)$.

\begin{abstract}
Na- $\beta^{\prime \prime}$-alumina is the commercially most successful solid electrolyte due to its application in ZEBRA and NAS ${ }^{\circledR}$ batteries. In this work, Li-stabilized Na- $\beta^{\prime \prime}$-alumina electrolytes were doped with $3 \mathrm{~d}$ transition metal oxides, namely $\mathrm{TiO}_{2}, \mathrm{Mn}_{3} \mathrm{O}_{4}$, and $\mathrm{NiO}$, in order to improve their ionic conductivity and fracture strength. Due to XRD and EDX measurements, it was concluded that Mnand $\mathrm{Ni}$-ions are incorporated into the crystal lattice of $\mathrm{Na}-\beta^{\prime \prime}$-alumina. In contrast, $\mathrm{TiO}_{2}$ doping results in the formation of secondary phases that enable liquid-assisted sintering at temperatures as low as $1500{ }^{\circ} \mathrm{C}$. All dopants increased the characteristic fracture strength of the electrolytes; $1.5 \mathrm{wt} \%$ of $\mathrm{NiO}$ doping proved to be most efficient and led to a maximal characteristic fracture strength of $296 \mathrm{MPa}$. Regarding the ionic conductivity, $\mathrm{TiO}_{2}$ doping showed the uppermost value of up to $0.30 \mathrm{~S} \mathrm{~cm}^{-1}$ at $300{ }^{\circ} \mathrm{C}$. In contrast to the other dopants, $\mathrm{TiO}_{2}$ doping lowered the sintering temperature needed to obtain a dense, stable, and highly conductive $\mathrm{Na}-\beta^{\prime \prime}$-alumina electrolyte suitable for applications in Na based batteries.
\end{abstract}

Keywords: doping; Na- $\beta^{\prime \prime}$-alumina; sodium-ion battery; sodium-ion conductor; solid electrolyte

\section{Introduction}

Due to their high conductivity for Na-ions compared to other solid electrolytes [1], polycrystalline electrolytes made from $\mathrm{Na}-\beta^{\prime \prime}$-alumina are established in commercial Nabatteries like ZEBRA or NAS ${ }^{\circledR}$ batteries since the 1990s [2]. The excellent conductivity for Na-ions is caused by highly conductive crystallographic planes occupied by Na-ions. The conduction planes are separated by two densely packed nonconductive spinel blocks, which results in a significant anisotropic conductivity within the crystallites. Accordingly, a high overall conductivity in a polycrystalline electrolyte body requires the presence of crystallites that provide a statistically distributed spatial orientation. In consequence, the electrolyte microstructure is of tremendous importance for material quality. Doping of $\mathrm{Na}-\beta^{\prime \prime}$-alumina with $3 \mathrm{~d}$ transition metals is known to influence the microstructure and is an excellent material scientific approach to optimize the electrolyte performance, and manufacturing processes them off. In the present paper, results from systematic doping experiments are reported, and fundamental mechanisms and correlations are derived.

The research on Na- $\beta$ "-alumina electrolytes has so far mainly focused on different production techniques [3-8] or the sintering behavior [9-11]. Some attention is also paid to improve the ionic conductivity and fracture strength of $\mathrm{Na}-\beta^{\prime \prime}$-alumina electrolytes by doping.

The high ionic conductivity of the $\mathrm{Na}-\beta^{\prime \prime}$-alumina electrolyte lowers the overall resistance of an electrochemical cell and increases, therefore, its efficiency. The fracture strength is important because $\mathrm{Na}-\beta^{\prime \prime}$-alumina electrolytes have to withstand temperature and pressure variations within a cell [12]. Furthermore, the necessary wall thickness of the electrolyte, and thereby the resistance, can be lowered if the characteristic fracture strength of the material is enlarged. Consequently, $3 \mathrm{~d}$ transition metal doping of $\mathrm{Na}-\beta^{\prime \prime}$-alumina can 
help to improve the electrochemical cell characteristics of sodium-based battery systems and strengthen their economic position.

$\mathrm{Na}-\beta^{\prime \prime}$-alumina is typically doped with $\mathrm{Mg}^{2+}$ or $\mathrm{Li}^{+}$to prevent decomposition of $\mathrm{Na}-\beta^{\prime \prime}$-alumina at the commonly applied sintering temperatures of about $1600^{\circ} \mathrm{C}[8,13,14]$. Typical compositions for stabilized $\mathrm{Na}-\beta^{\prime \prime}$-alumina electrolytes are $\mathrm{Na}_{1.67} \mathrm{Mg}_{0.67} \mathrm{Al}_{10.33} \mathrm{O}_{17}$ or $\mathrm{Na}_{1.67} \mathrm{Li}_{0.33} \mathrm{Al}_{10.67} \mathrm{O}_{17}[13,15,16]$.

Additionally, up to $15 \mathrm{vol} \% \mathrm{ZrO}_{2}$ is a common dopant that inhibits extensive grain growth of Na- $\beta^{\prime \prime}$-alumina grains by forming intergranular $\mathrm{ZrO}_{2}$ particles. However, the addition of isolating $\mathrm{ZrO}_{2}$ is known to lower the ionic conductivity of Na- $\beta^{\prime \prime}$-alumina electrolytes $[8,17,18]$.

$3 \mathrm{~d}$ transition metal doping has shown a high potential to promote ionic conductivity and characteristic fracture strength [13,19-22]. Nevertheless, the measured conductivities are difficult to compare because different reactants for synthesis, co-dopants, synthesis routes, and measuring temperatures were used from various researches [23-26]. For this reason, three promising $3 \mathrm{~d}$ metal dopants for $\mathrm{Na}-\beta^{\prime \prime}$-alumina, namely $\mathrm{TiO}_{2}, \mathrm{Mn}_{3} \mathrm{O}_{4}$, and $\mathrm{NiO}$, are of interest in this work.

Compared to other $3 \mathrm{~d}$ dopants, Ti doping was under investigation in literature repeatedly $[13,21,23,24]$. It has shown the most beneficial influence on the ionic conductivity of Na- $\beta^{\prime \prime}$-alumina. The reasons for this large improvement compared to other dopants is not clear yet. Lu et al. [27] proposed but did not observe the formation of a transient liquid phase containing compounds such as $\mathrm{Na}_{2} \mathrm{Ti}_{3} \mathrm{O}_{7}, \mathrm{Na}_{8} \mathrm{Ti}_{5} \mathrm{O}_{14}$, or $\mathrm{Na}_{2} \mathrm{Ti}_{6} \mathrm{O}_{13}$. The liquid phase could form at temperatures of about $1300{ }^{\circ} \mathrm{C}$ and promote the densification process. Furthermore, an increased number of $\mathrm{Al}^{3+}$ vacancies could promote diffusion and thereby improve the sintering behavior. This mechanism is widely accepted for the increased densification of $\mathrm{TiO}_{2}$-doped $\mathrm{Al}_{2} \mathrm{O}_{3}[28,29]$.

This process also might be possible for $\mathrm{Mn}$ - or $\mathrm{Ni}$-doped $\mathrm{Na}-\beta^{\prime \prime}$-alumina.

A comprehensive evaluation of Mn-doped $\mathrm{Na}-\beta^{\prime \prime}$-alumina has not been published so far. Kennedy et al. [25] doped $\mathrm{Mg}^{2+}$ stabilized $\mathrm{Na}-\beta^{\prime \prime}$-alumina with 1,2 , and $4 \mathrm{wt} \%$ $\mathrm{Mn}\left(\mathrm{NO}_{3}\right)_{2}$ and found an increase of the ionic conductivity from 0.018 to $0.025 \mathrm{~S} \mathrm{~cm}^{-1}$ at $300{ }^{\circ} \mathrm{C}$ for a doping amount of $4 \mathrm{wt} \%$. The characteristic fracture strength and the influence of different sintering regimes were not analyzed. Lu et al. [27] tested co-doped $\mathrm{Na}-\beta^{\prime \prime}$-alumina $\left(5 \mathrm{wt} \% \mathrm{Mn}\left(\mathrm{NO}_{3}\right)_{2}, \mathrm{Ti}\left(\mathrm{OCH}\left(\mathrm{CH}_{3}\right)_{2}\right)_{4}\right.$, and $\left.\mathrm{ZrO}_{2}\right)$. The ionic conductivity or the characteristic fracture strength of $\mathrm{Mn}\left(\mathrm{NO}_{3}\right)_{2}$-single-doped $\mathrm{Na}-\beta^{\prime \prime}$-alumina was not reported, but Lu et al. noted a slightly increased shrinkage while sintering $\mathrm{Mn}\left(\mathrm{NO}_{3}\right)_{2-}$ doped Na- $\beta^{\prime \prime}$-alumina.

Zhu et al. [20] and Kennedy et al. systematically investigated Ni-doped Na- $\beta^{\prime \prime}$ alumina [25]. Zhu et al. found a conductivity maximum by doping with $0.25 \mathrm{wt} \% \mathrm{NiO}$ $\left(0.066 \mathrm{~S} \mathrm{~cm}^{-1}\right.$ at $\left.350{ }^{\circ} \mathrm{C}\right)$, while Kennedy et al. found a steady increase of the conductivity up to the maximum tested doping amount of $4 \mathrm{wt} \% \mathrm{Ni}\left(\mathrm{NO}_{3}\right)_{2}\left(0.047 \mathrm{~S} \mathrm{~cm}^{-1}\right.$ at $\left.300{ }^{\circ} \mathrm{C}\right)$. Both reported ionic conductivities are in comparison to undoped $\mathrm{Na}-\beta^{\prime \prime}$-alumina in other publications well below the average $[4,30]$. This indicates a poor microstructure, a low relative density, a low phase content, or other barriers. Moreover, Zhu et al. reported a bending strength, which increased from 194 to $296 \mathrm{MPa}$ after the addition of $0.25 \mathrm{wt} \% \mathrm{NiO}$ [20].

Here, we close the lack of comparable and comprehensive data regarding $3 \mathrm{~d}$ transition metal doping of Na- $\beta^{\prime \prime}$-alumina. Therefore, this work cites and extends some results of a former publication [13] of the authors about $\mathrm{TiO}_{2}$ doping. Furthermore, it investigates the key characteristics, such as conductivity and characteristic fracture strength of $\mathrm{Mn}_{3} \mathrm{O}_{4}$ and $\mathrm{NiO}$-doped $\mathrm{Na}-\beta^{\prime \prime}$-alumina electrolytes at different doping amounts and sintering temperatures. In contrast to previous studies, various dopants, doping amounts, and sintering temperatures were tested. Density, SEM-EDX, and XRD studies were carried out to further investigate the so far poorly addressed mechanisms of $3 \mathrm{~d}$ transition metal doping of Na- $\beta^{\prime \prime}$-alumina. 


\section{Materials and Methods}

\subsection{Sample Preparation}

$\mathrm{AlO}(\mathrm{OH})$ (>98\%; Nabaltec, Schwandorf, Germany), $\mathrm{Na}_{2} \mathrm{CO}_{3}$ (>99\%; Carl Roth, Karlsruhe, Germany), and $\mathrm{Li}_{2} \mathrm{CO}_{3}$ (>99.8\%; Carl Roth, Karlsruhe, Germany) were mixed in the stoichiometry $\mathrm{Na}_{1.67} \mathrm{Al}_{10.67} \mathrm{Li}_{0.33} \mathrm{O}_{17}$. Afterwards, the powder was calcined at $1280{ }^{\circ} \mathrm{C} / 2 \mathrm{~h}$ in $\mathrm{MgO}$ crucibles. The obtained white powder was mixed with $\mathrm{TiO}_{2}(>99.7 \%$; Alfa Aesar, Haverhill, MA, USA) or NiO (>99\%; Lomberg Chemie, Oberhausen, Germany) without any further treatment. $\mathrm{MnO}_{2}(>98 \%$; Carl Roth, Karlsruhe, Germany) was oxidized to $\mathrm{Mn}_{3} \mathrm{O}_{4}\left(650{ }^{\circ} \mathrm{C} / 5 \mathrm{~h}\right)$ before using it as a dopant. The powder mixture was then suspended in EtOH and ball milled in $\mathrm{ZrO}_{2}$ beakers for $0.5 \mathrm{~h}$. After drying $\left(80{ }^{\circ} \mathrm{C} / 12 \mathrm{~h}\right)$, granulating (with an organic binder), and pressing (up to $110 \mathrm{kN}$ ), the ceramic green bodies were sintered under air atmosphere at $1500{ }^{\circ} \mathrm{C}, 1600{ }^{\circ} \mathrm{C}$, or $1700{ }^{\circ} \mathrm{C}$ for $0.5 \mathrm{~h}$. This resulted in transition-metal-doped solid electrolyte bodies. To calculate the molar ratio presented in Section 3, the amount of added transition metal ions was divided by the amount of $\mathrm{Na}-\beta^{\prime \prime}$-alumina with the stoichiometry $\mathrm{Na}_{1.67} \mathrm{Al}_{10.67} \mathrm{Li}_{0.33} \mathrm{O}_{17}$. The mass fraction of the dopants is always given in percentage.

\subsection{Sample Characterization}

XRD patterns were measured from grounded disks (D8 Advance, Bruker, Billerica, MA, USA). The quantitative XRD evaluation was performed by the Rietveld refinement method (Autoquan 2.8.0.2).

Density analysis was carried out via Archimedes' principle in toluene.

The absolute density was measured by a He-Pycnometer (Pyknomatik-ATC, Thermo Fisher, Waltham, MA, USA).

To take SEM images (Ultra 55+, Carl Zeiss, Oberkochen, Germany), fractured disks were used. SEM-EDX-scans (Ultra 55+, Carl Zeiss, Oberkochen, Germany/Trident XM4, EDAX, Mahwah, NJ, USA) were taken from polished disks.

The fracture strength was tested on ten sintered tablets per doping level by ballon-three-balls method (Zwick 100, Zwick, Ulm, Germany). The data were evaluated by Weibull statistics (maximum likelihood estimation).

Ionic conductivities were measured from bar-shaped samples. The measurements were carried out at two separately sintered bars of each sample by impedance spectroscopy (SP-240, Biologic, Seyssinet-Pariset, France and Reference 3000 AE, Gamry Instruments, Warminister, PA, USA) at a temperature of $300{ }^{\circ} \mathrm{C}$. The range of the applied frequencies was from $1 \mathrm{MHz}$ to $9 \mathrm{~Hz}$. The sinus amplitude was set to $10 \mathrm{mV}$. Figure 1 displays the equivalent circuit, which was used to fit the Nyquist plots. The bulk- $\left(R_{b}\right)$ and the grain boundary resistance $\left(R_{\mathrm{gb}}\right)$ were selected from the regression analysis curve to calculate the resistance $(\mathrm{R})$ of the sample Equation (1).

$$
R=R_{b}+R_{g b}
$$

To calculate the ionic conductivity $(\sigma)$, Equation (2) was used. L represents the length of the sample and A, the cross-sectional area.

$$
\sigma=\frac{L}{A \cdot R}
$$

The calculation of the specific grain boundary resistance $\left(R_{\mathrm{sgb}}\right)$ was done by Equation (3).

$$
R_{s g b}=\frac{A \cdot R_{g b}}{L}
$$

The measurements were realized in the sample-holders shown in a previous publication [13]. 


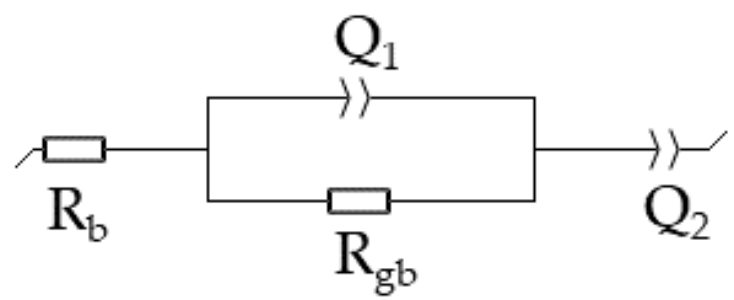

Figure 1. Equivalent circuit used for fitting the Nyquist plot. $R_{b}$ represents the starting point of the semicircle at high frequencies. $R_{g b}$ and the constant phase element $Q_{1}$ represent the size of the semicircle. $Q_{2}$ represents the low-frequency area caused by electric contact and is of no further interest for this work.

\section{Results}

\subsection{XRD Analysis}

To verify the phase composition and detect any secondary phases of the Na- $\beta^{\prime \prime}$ alumina electrolytes, XRDs were recorded. Firstly, the undoped reference materials after sintering at temperatures of $1500{ }^{\circ} \mathrm{C}, 1600{ }^{\circ} \mathrm{C}$, and $1700{ }^{\circ} \mathrm{C}$ were measured as can be seen in Figure 2. The diffraction patterns are in good agreement with the literature-reported reflexes of Na- $\beta^{\prime \prime}$-alumina. The reflexes at $30.2^{\circ}$ and $33.6^{\circ}$ can be addressed to $\mathrm{NaAlO}_{2}$ impurities. Rietveld refinement gave a Na- $\beta^{\prime \prime}$-alumina phase content of $>95 \%$ for all three samples. The exact results are displayed in Table 1 . As a difference in between the samples, the reflex 006 at $15.8^{\circ}$ leaps to the eye. The reflex shows an increasing intensity as the sintering temperature rises. Li et al. [31] addressed this phenomenon to increasing anisotropic grain growth.

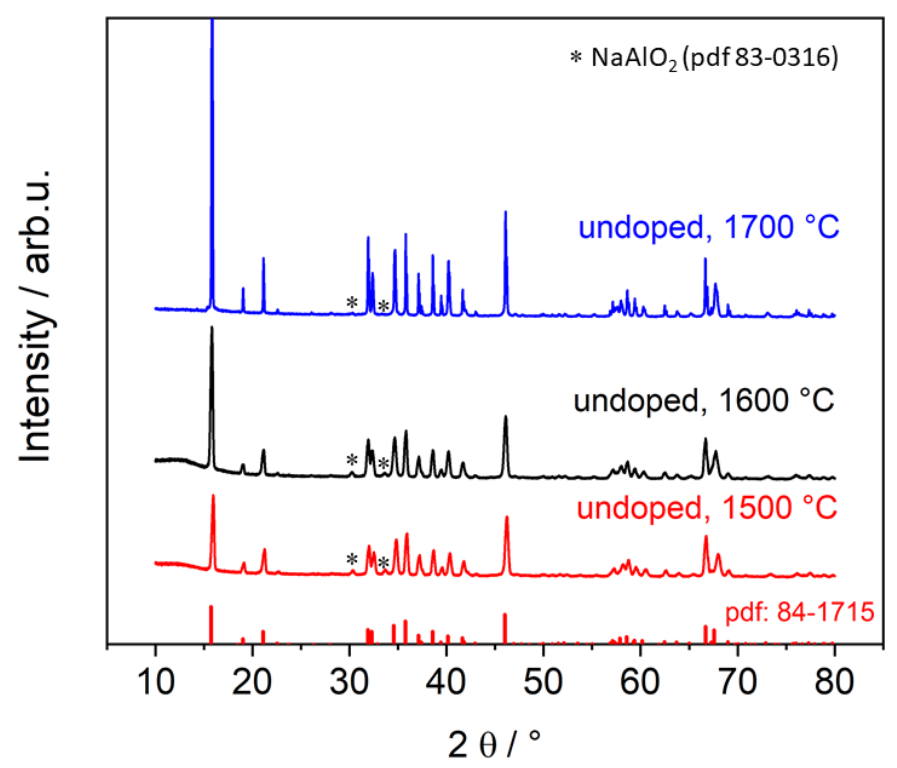

Figure 2. Diffraction patterns of undoped Na- $\beta^{\prime \prime}$-alumina sintered at $1500{ }^{\circ} \mathrm{C}, 1600{ }^{\circ} \mathrm{C}$, or $1700{ }^{\circ} \mathrm{C}$. The literature reflexes of Na- $\beta^{\prime \prime}$-alumina (pdf 84-1715) are illustrated by the red bars at the bottom. The reflex $006\left(15.8^{\circ}\right)$ is clipped off.

Table 1. Na- $\beta$ "-alumina phase content $[w t \%]$ of differently sintered and doped samples.

\begin{tabular}{|c|c|c|c|c|c|c|c|}
\hline \multirow[b]{2}{*}{$\begin{array}{c}\text { Doping } \\
\text { Amount/wt } \%\end{array}$} & \multicolumn{3}{|c|}{$\mathrm{TiO}_{2}$ Doped } & \multicolumn{2}{|c|}{$\mathrm{Mn}_{3} \mathrm{O}_{4}$ Doped } & \multicolumn{2}{|c|}{ NiO Doped } \\
\hline & $1500{ }^{\circ} \mathrm{C}$ & $1600^{\circ} \mathrm{C}$ & $1700^{\circ} \mathrm{C}$ & $1600^{\circ} \mathrm{C}$ & $1700^{\circ} \mathrm{C}$ & $1600^{\circ} \mathrm{C}$ & $1700^{\circ} \mathrm{C}$ \\
\hline 0 & $96.4 \pm 0.1$ & $96.3 \pm 0.5$ & $95.5 \pm 1.7$ & $96.3 \pm 0.5$ & $95.5 \pm 1.7$ & $96.3 \pm 0.5$ & $95.5 \pm 1.7$ \\
\hline 0.5 & $96.4 \pm 0.4$ & $96.6 \pm 0.4$ & $96.2 \pm 0.3$ & $94.9 \pm 0.3$ & $93.8 \pm 3.6$ & $97.0 \pm 0.1$ & $94.6 \pm 0.5$ \\
\hline 1.0 & $96.8 \pm 0.5$ & $96.4 \pm 0.4$ & $98.0 \pm 0.4$ & $94.1 \pm 4.1$ & $94.4 \pm 1.0$ & $96.3 \pm 0.4$ & $95.2 \pm 0.5$ \\
\hline
\end{tabular}


Table 1. Cont.

\begin{tabular}{|c|c|c|c|c|c|c|c|}
\hline \multirow[b]{2}{*}{$\begin{array}{c}\text { Doping } \\
\text { Amount } / w t \%\end{array}$} & \multicolumn{3}{|c|}{$\mathrm{TiO}_{2}$ Doped } & \multicolumn{2}{|c|}{$\mathrm{Mn}_{3} \mathrm{O}_{4}$ Doped } & \multicolumn{2}{|c|}{ NiO Doped } \\
\hline & $1500{ }^{\circ} \mathrm{C}$ & $1600^{\circ} \mathrm{C}$ & $1700^{\circ} \mathrm{C}$ & $1600{ }^{\circ} \mathrm{C}$ & $1700^{\circ} \mathrm{C}$ & $1600^{\circ} \mathrm{C}$ & $1700^{\circ} \mathrm{C}$ \\
\hline 1.5 & $95.5 \pm 0.5$ & $94.0 \pm 0.6$ & $94.1 \pm 1.0$ & $95.7 \pm 0.5$ & $95.3 \pm 1.0$ & $96.7 \pm 1.5$ & $96.7 \pm 0.2$ \\
\hline 2.0 & $96.3 \pm 0.8$ & $95.9 \pm 0.5$ & $90.8 \pm 0.6$ & $93.5 \pm 0.3$ & $95.6 \pm 2.4$ & $94.8 \pm 0.2$ & $97.1 \pm 0.5$ \\
\hline 2.5 & $94.8 \pm 0.5$ & $95.3 \pm 0.2$ & $96.7 \pm 0.8$ & $95.2 \pm 0.2$ & $93.9 \pm 2.1$ & $94.4 \pm 0.2$ & $96.8 \pm 0.9$ \\
\hline 5.0 & $96.6 \pm 1.1$ & $92.5 \pm 0.3$ & $94.2 \pm 1.7$ & $93.9 \pm 1.6$ & $93.2 \pm 0.9$ & $95.5 \pm 0.3$ & $95.6 \pm 1.2$ \\
\hline
\end{tabular}

\subsubsection{Phase Composition of $\mathrm{TiO}_{2}$-Doped Electrolytes}

XRD patterns of $\mathrm{TiO}_{2}$-doped $\mathrm{Na}-\beta^{\prime \prime}$-alumina, displayed in Figure 3, also show a high agreement with literature-reported reflexes. The Na- $\beta^{\prime \prime}$-alumina phase content of all the $\mathrm{TiO}_{2}$-doped samples is constantly about $95 \%$. Neither doping amount nor sintering temperature has a large influence, as displayed in Table 1.

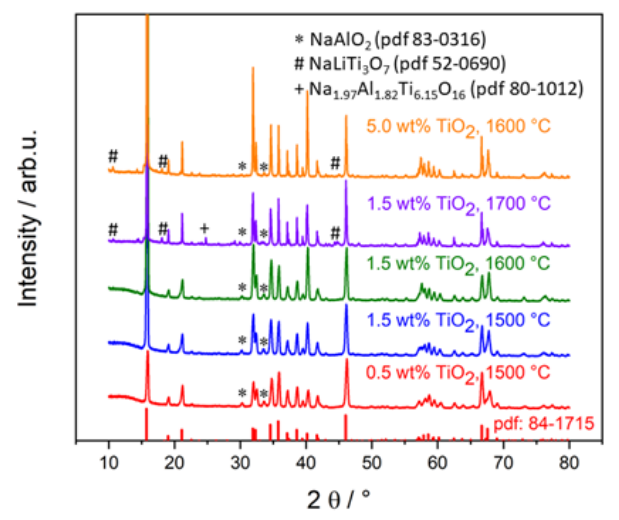

(a)

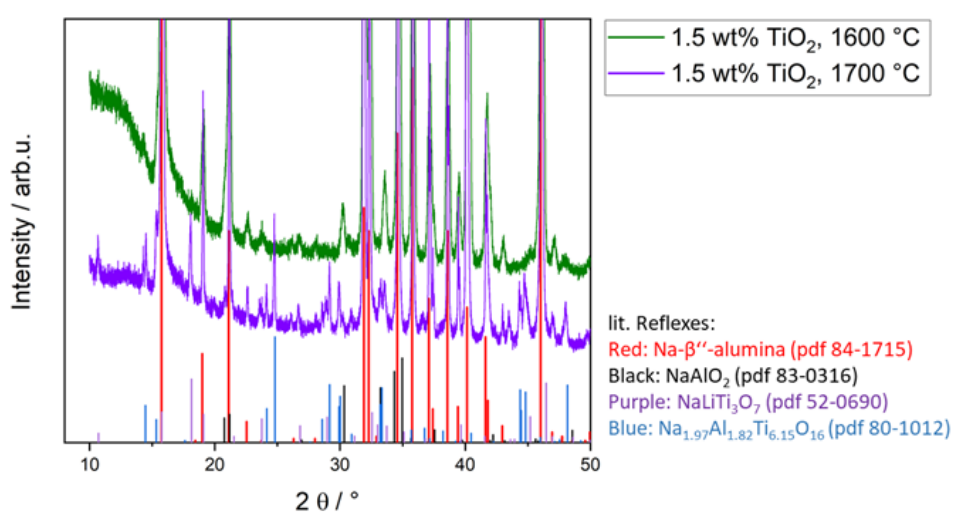

(b)

Figure 3. (a) Diffraction patterns of $\mathrm{TiO}_{2}$-doped $\mathrm{Na}-\beta^{\prime \prime}$-alumina samples. The reflex $006\left(15.9^{\circ}\right)$ is clipped off. The literature reflexes at the bottom are taken from pdf 84-1715. (b) XRD fingerprint of two $\mathrm{TiO}_{2}$-doped Na- $\beta^{\prime \prime}$-alumina samples with $\mathrm{Na}-\beta^{\prime \prime}$-alumina literature reflexes at the bottom.

Diffraction patterns of samples with lower $\mathrm{TiO}_{2}$ doping amounts $(\leq 2.5 \mathrm{wt} \%)$ and lower sintering temperatures $\left(\leq 1600^{\circ} \mathrm{C}\right)$ do not indicate the formation of any secondary phases besides $\mathrm{Na}-\beta^{\prime \prime}$-alumina, $\mathrm{NaAlO}_{2}$, and some negligible amounts of $\mathrm{Na}-\beta$-alumina. XRD patterns of highly doped samples and/or samples sintered at $1700{ }^{\circ} \mathrm{C}$ clearly show the formation of two additional phases next to $\mathrm{NaAlO}_{2}$ and $\mathrm{Na}-\beta^{\prime \prime}$-alumina, namely $\mathrm{NaLiTi}_{3} \mathrm{O}_{7}$ and $\mathrm{Na}_{1.97} \mathrm{Al}_{1.82} \mathrm{Ti}_{6.15} \mathrm{O}_{16}$. Those secondary phases might also be present in samples from sintering at lower temperatures, but they are not detectible by XRD due to a lower crystalline fraction of small crystallites. The latter phenomenon would lead to spread out reflexes, which cannot be detected under the noise (compare XRD amorphousness). Figure $3 \mathrm{~b}$ exemplarily presents the fingerprint areas of a sample doped with $1.5 \mathrm{wt} \%$ $\mathrm{TiO}_{2}$ and a sintering temperature of $1700^{\circ} \mathrm{C}$, with clearly visible secondary phases beside $\mathrm{NaAlO}_{2}$. Additionally, the same section of an XRD pattern taken from a sample with the same doping amount but a sintering temperature of only $1600^{\circ} \mathrm{C}$ is depicted. Here, no clear secondary phases besides $\mathrm{NaAlO}_{2}$ are detected.

Wei et al. [21] found an increase of the Na- $\beta^{\prime \prime}$-alumina phase content of $1.9 \%$ by doping with $1.75 \mathrm{wt} \% \mathrm{TiO}_{2}$, while Yi et al. [18] reported a decrease for all tested doping amounts. Neither of those researchers nor other ones observed any Ti-containing secondary phase $[21,23,27,32]$. This is in line with the results in this work since samples doped as high as $5.0 \mathrm{wt} \% \mathrm{TiO}_{2}$ or sintering temperatures of $1700{ }^{\circ} \mathrm{C}$ were not described in those publications. 
The lattice parameters of the Na- $\beta^{\prime \prime}$-alumina phase were calculated for all doped samples sintered at $1600^{\circ} \mathrm{C}$ from XRD data. In Figure 4, the results are given comparatively. The lattice parameters do not show a significant dependency between the amount of dopant and spread around the mean value of $0.5614 \mathrm{~nm} \pm 0.0002 \mathrm{~nm}$ (parameter $\mathrm{a}, \mathrm{b}$ ) or $3.368 \mathrm{~nm} \pm 0.002 \mathrm{~nm}$ (parameter c).

Boilot et al. [33] proposed that ions with radii smaller than $0.097 \mathrm{~nm}$ can substitute Alions in the Na- $\beta^{\prime \prime}$ alumina lattice and stabilize the Na- $\beta^{\prime \prime}$-alumina phase. This is valid for all three tested dopants. However, the constant lattice parameters of $\mathrm{TiO}_{2}$-doped samples do not support the assumption that Ti-ions substitute Al-ions under the synthesis conditions tested in this work.
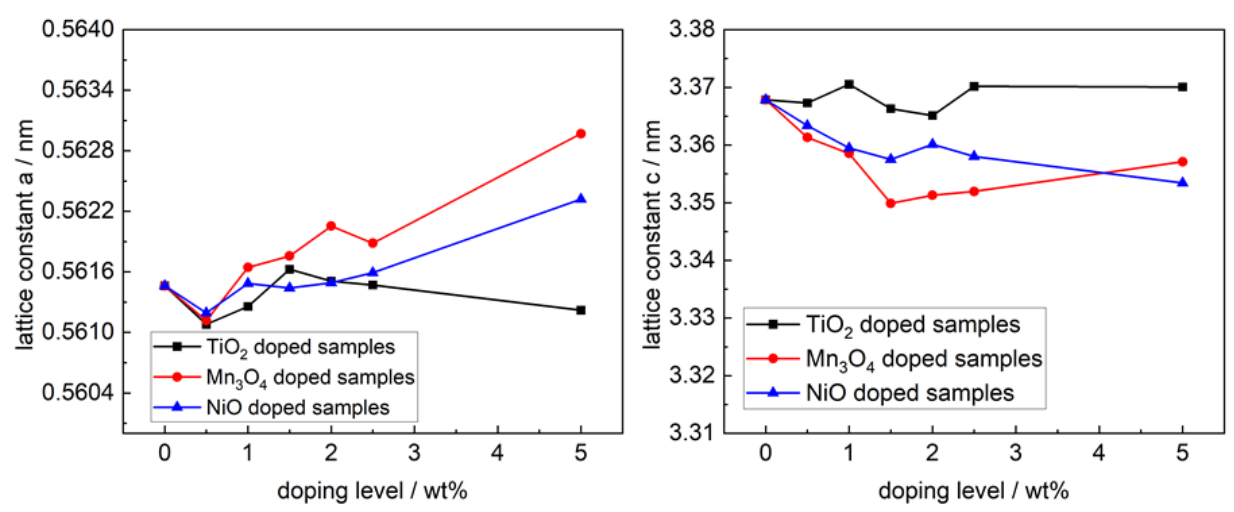

Figure 4. Crystallographic lattice parameters a and c of Na- $\beta^{\prime \prime}$-alumina samples sintered at $1600{ }^{\circ} \mathrm{C}$.

\subsubsection{Phase Composition of $\mathrm{Mn}_{3} \mathrm{O}_{4}$ - and NiO-Doped Electrolytes}

The XRD measurements of $\mathrm{Mn}_{3} \mathrm{O}_{4}$ - and $\mathrm{NiO}$-doped $\mathrm{Na}-\beta^{\prime \prime}$-alumina electrolytes reveal no secondary phases besides $\mathrm{NaAlO}_{2}$ and minor amounts of $\mathrm{Na}-\beta$-alumina. They also reveal a high agreement with the literature diffractogram of Na- $\beta^{\prime \prime}$-alumina, as Figure 5 exemplarily shows. The Na- $\beta^{\prime \prime}$-alumina phase contents listed in Table 1 indicate that $\mathrm{Mn}_{3} \mathrm{O}_{4^{-}}$and $\mathrm{NiO}$ doping do not heavily affect the Na- $\beta^{\prime \prime}$-alumina phase content. Zhu et al. [20] found an increased Na- $\beta^{\prime \prime}$-alumina phase content from $92.3 \%$ to $98.9 \%$ by doping with $0.25 \mathrm{wt} \% \mathrm{NiO}$. In contrast to this work, Zhu. et al. used the intensity relation of a $\mathrm{Na}-\beta^{\prime \prime}$-alumina reflex and a Na- $\beta$-alumina reflex to calculate the phase content. Phases such as $\mathrm{Al}_{2} \mathrm{O}_{3}$ or $\mathrm{NaAlO}_{2}$ were not taken into account.

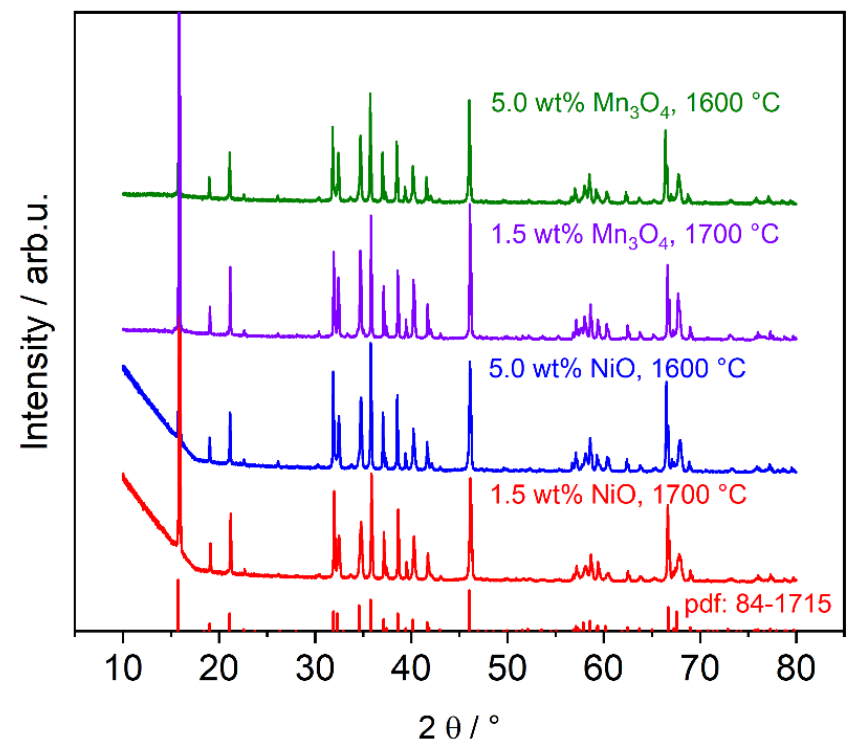

Figure 5. Diffraction patterns of $\mathrm{Mn}_{3} \mathrm{O}_{4}$ - and $\mathrm{NiO}$-doped $\mathrm{Na}-\beta^{\prime \prime}$-alumina. The reflex $006\left(15.9^{\circ}\right)$ is clipped off. The literature reflexes of $\mathrm{Na}-\beta^{\prime \prime}$-alumina (pdf 84-1715) are illustrated by the red bars at the bottom. 
The lattice parameters $\mathrm{a}$ and $\mathrm{b}$ of $\mathrm{Mn}_{3} \mathrm{O}_{4}$ - and $\mathrm{NiO}$-doped samples (Figure 4) increased slightly from $0.5615 \mathrm{~nm}$ to $0.5644 \mathrm{~nm}$ and $0.5618 \mathrm{~nm}$ due to a doping amount of $5.0 \mathrm{wt} \%$. The lattice parameter c decreased at the same doping amount from $3.3679 \mathrm{~nm}$ to $3.3571 \mathrm{~nm}$ and $3.3536 \mathrm{~nm}$, respectively. A change of the lattice constant, likely caused by different radii and electrostatic effects, hints at the $\mathrm{Na}-\beta^{\prime \prime}$-alumina lattice incorporated $\mathrm{Mn}$ - and Ni-ions.

\subsection{Density Analysis}

A high relative density of the sintered $\mathrm{Na}-\beta^{\prime \prime}$-alumina electrolytes is desirable because pores hinder the Na-ions passing through the electrolyte in the shortest possible way. Thereby, the ionic resistance of the electrolyte rises. Additionally, pores weaken the microstructure of the electrolyte resulting in lower fracture strength.

\subsubsection{Density of $\mathrm{TiO}_{2}$-Doped Na- $\beta^{\prime \prime}$-Alumina}

Figure 6 a displays the relative density of $\mathrm{TiO}_{2}$-doped $\mathrm{Na}-\beta^{\prime \prime}$-alumina. The peak densities are achieved by a sintering temperature of $1500{ }^{\circ} \mathrm{C}$ and a doping amount of $1.0 \mathrm{wt} \%\left(99.6 \% / 3.18 \mathrm{~g} \mathrm{~cm}^{-3}\right)$. A temperature of $1600{ }^{\circ} \mathrm{C}$ leads to slightly lower densities with a maximum at $1 \mathrm{wt} \%$ doping $\left(98.1 \% / 3.14 \mathrm{~g} \mathrm{~cm}^{-3}\right)$. Even higher doping amounts lead to a density drop. Similar behavior was found at sintering temperatures of $1700^{\circ} \mathrm{C}$. The maximum is reached at $1 \mathrm{wt} \% \mathrm{TiO}_{2}$, but density reaches only $96.4 \% / 3.09 \mathrm{~g} \mathrm{~cm}^{-3}$. Hence, $1 \mathrm{wt} \%$ of $\mathrm{TiO}_{2}$ doping leads to a density maximum regardless of the sintering temperature. Higher doping amounts and sintering temperatures lead to relatively lower densities. The higher density hints towards a liquid-assisted sintering process at a sintering temperature of $1500{ }^{\circ} \mathrm{C}$. The porosity increased most likely in consequence of oversintering, caused by pore agglomeration, and increased sublimation of $\mathrm{Na}_{2} \mathrm{O}$ (sublimating point $1275^{\circ} \mathrm{C}$ ) [34].
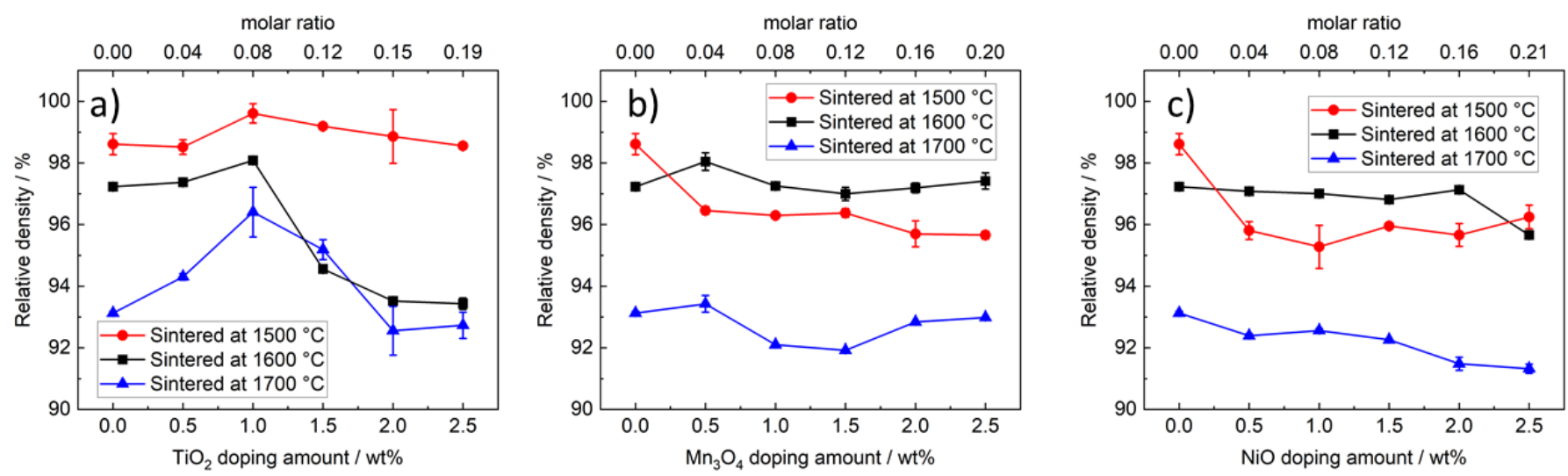

Figure 6. (a) Relative density of $\mathrm{TiO}_{2}$-doped $\mathrm{Na}-\beta^{\prime \prime}$-alumina samples; (b) relative density of $\mathrm{Mn}_{3} \mathrm{O}_{4}$-doped Na- $\beta^{\prime \prime}$-alumina samples; (c) relative density of $\mathrm{NiO}$-doped $\mathrm{Na}-\beta^{\prime \prime}$-alumina samples.

\subsubsection{Density of $\mathrm{Mn}_{3} \mathrm{O}_{4}$ - and NiO-Doped Na- $\beta^{\prime \prime}$-Alumina}

Figure $6 \mathrm{~b}$ shows the influence of $\mathrm{Mn}_{3} \mathrm{O}_{4}$ doping on the relative densities of $\mathrm{Na}-\beta^{\prime \prime}$ alumina. Samples sintered at $1600{ }^{\circ} \mathrm{C}$ or $1700{ }^{\circ} \mathrm{C}$ show relative densities of about $97.5 \%$ and $93.0 \%$, respectively, not depending on the doping amount. The density of samples sintered at $1500{ }^{\circ} \mathrm{C}$ drops from $98.6 \% / 3.16 \mathrm{~g} \mathrm{~cm}^{-3}$ to $96.0 \% / 3.11 \mathrm{~g} \mathrm{~cm}^{-3}$ due to $0.5 \mathrm{wt} \%$ of $\mathrm{Mn}_{3} \mathrm{O}_{4}$ doping.

The relative density of $\mathrm{NiO}$-doped $\mathrm{Na}-\beta^{\prime \prime}$-alumina (Figure $6 \mathrm{c}$ ) has a minimal downward tendency after sintering at $1600{ }^{\circ} \mathrm{C}$ or $1700{ }^{\circ} \mathrm{C}$. At sintering temperatures of $1500{ }^{\circ} \mathrm{C}$, a similar trend to $\mathrm{Mn}_{3} \mathrm{O}_{4}$-doped samples can be observed; $0.5 \mathrm{wt} \%$ of $\mathrm{NiO}$ doping reduces the relative density from $98.6 \% / 3.16 \mathrm{~g} \mathrm{~cm}^{-3}$ to $96.0 \% / 3.11 \mathrm{~g} \mathrm{~cm}^{-3}$.

In summary, $\mathrm{Mn}_{3} \mathrm{O}_{4}$ and $\mathrm{NiO}$ doping shows a slight influence on the relative density at sintering temperatures of $1600^{\circ} \mathrm{C}$ and $1700{ }^{\circ} \mathrm{C}$, while the relative density is lowered at sintering temperatures of $1500{ }^{\circ} \mathrm{C}$. 


\subsection{SEM and EDX Analysis}

To analyze the influence of $3 \mathrm{~d}$ transition metal doping and the sintering temperature on the microstructure, SEM studies were carried out. Subsequently, an EDX mapping was performed to investigate the dopant distribution within the microstructure.

\subsubsection{Influence of $\mathrm{TiO}_{2}$ Doping on the Microstructure}

Figure 7 illustrates the impact of $\mathrm{TiO}_{2}$ doping on $\mathrm{Na}-\beta^{\prime \prime}$-alumina samples for different sintering regimes. For undoped samples, a drastic microstructure changes from sintering temperatures of $1500{ }^{\circ} \mathrm{C}$ to $1700{ }^{\circ} \mathrm{C}$ is obvious (Figure $7 \mathrm{a}-\mathrm{c}$ ). The microstructure is characterized by fine grains $(<10 \mu \mathrm{m})$ after sintering at $1500{ }^{\circ} \mathrm{C}$, while higher temperatures result in extensive grain growth and pores with a diameter of up to $20 \mu \mathrm{m}$ (Figure $7 \mathrm{a}-\mathrm{c}$ ). Figure $7 \mathrm{~d}$, e shows $\mathrm{Na}-\beta^{\prime \prime}$-alumina doped with $1.5 \mathrm{wt} \% \mathrm{TiO}_{2}$ sintered at $1500^{\circ} \mathrm{C}, 1600{ }^{\circ} \mathrm{C}$, or $1700^{\circ} \mathrm{C}$. The most apparent change originating from $\mathrm{TiO}_{2}$ doping was found for a sintering temperature of $1500^{\circ} \mathrm{C}$. In comparison to the undoped sample, large and strongly anisotropic, directional grown grains are present. Sintering temperatures above $1500{ }^{\circ} \mathrm{C}$ result in more pores. The increase is in good agreement with the observed decreased relative densities of samples sintered at higher temperatures.
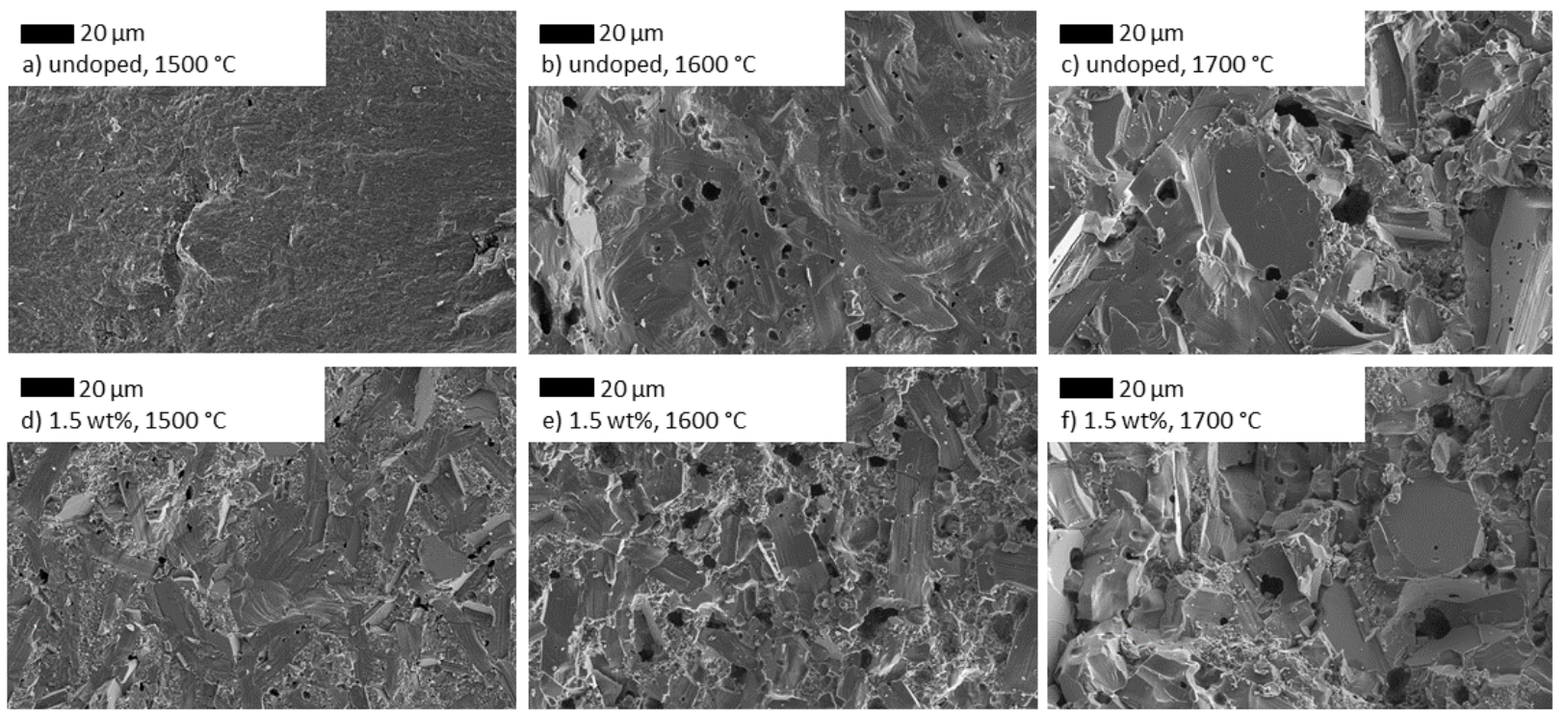

Figure 7. SEM images of Na- $\beta^{\prime \prime}$-alumina samples sintered at $1500{ }^{\circ} \mathrm{C}, 1600{ }^{\circ} \mathrm{C}$, or $1700{ }^{\circ} \mathrm{C}$; (a-c) undoped samples; (d-f) Na- $\beta^{\prime \prime}$-alumina doped with $1.5 \mathrm{wt} \% \mathrm{TiO}_{2}$. Images $(\mathbf{a}, \mathbf{b}, \mathbf{d}, \mathbf{e})$ were rearranged and reprinted with permission from Dirksen et al. [13].

The influence of different $\mathrm{TiO}_{2}$-doping amounts at a constant sintering temperature on the microstructure is depicted in Figure 8. A doping amount of $0.5 \mathrm{wt} \%$ does not reveal any changes in comparison to an undoped sample, but $1.0 \mathrm{wt} \%$ of $\mathrm{TiO}_{2}$ doping results in occasional large crystals with a diameter of about $100 \mu \mathrm{m}$. Even higher doping amounts cause a microstructure dominated by large crystals but smaller pores than the samples sintered at $1600^{\circ} \mathrm{C}$.

To further investigate the influence of $\mathrm{TiO}_{2}$ doping on the microstructure of $\mathrm{Na}-\beta^{\prime \prime}$ alumina, backscattering SEM, EDX mapping (Figure 9), and EDX spot analysis (Figure 10) were performed. Ti was not located by EDX mapping or an EDX spot analysis in the sample slightly doped with $0.5 \mathrm{wt} \% \mathrm{TiO}_{2}$ (Figure 9a). The EDX mapping of the sample doped with $2.0 \mathrm{wt} \%$ revealed areas of fine grains $(<10 \mu \mathrm{m})$, where Ti was detected, while large grains $(>20 \mu \mathrm{m})$ were completely free of Ti. The sample doped with $5.0 \mathrm{wt} \%$ showed a clear phase separation: dark-appearing grains having a low mean atomic number originating potentially from phases comprising solely $\mathrm{Na}, \mathrm{Al}$, and $\mathrm{O}$, and in-between light-appearing grains having a higher mean atomic number potentially originating from additionally Ti. 
The Al mapping reveals a decreasing Al content within the brighter phase. The Na content within the bright phase is uneven, and only some areas show an increased Na content (best visible in Figure 9c).

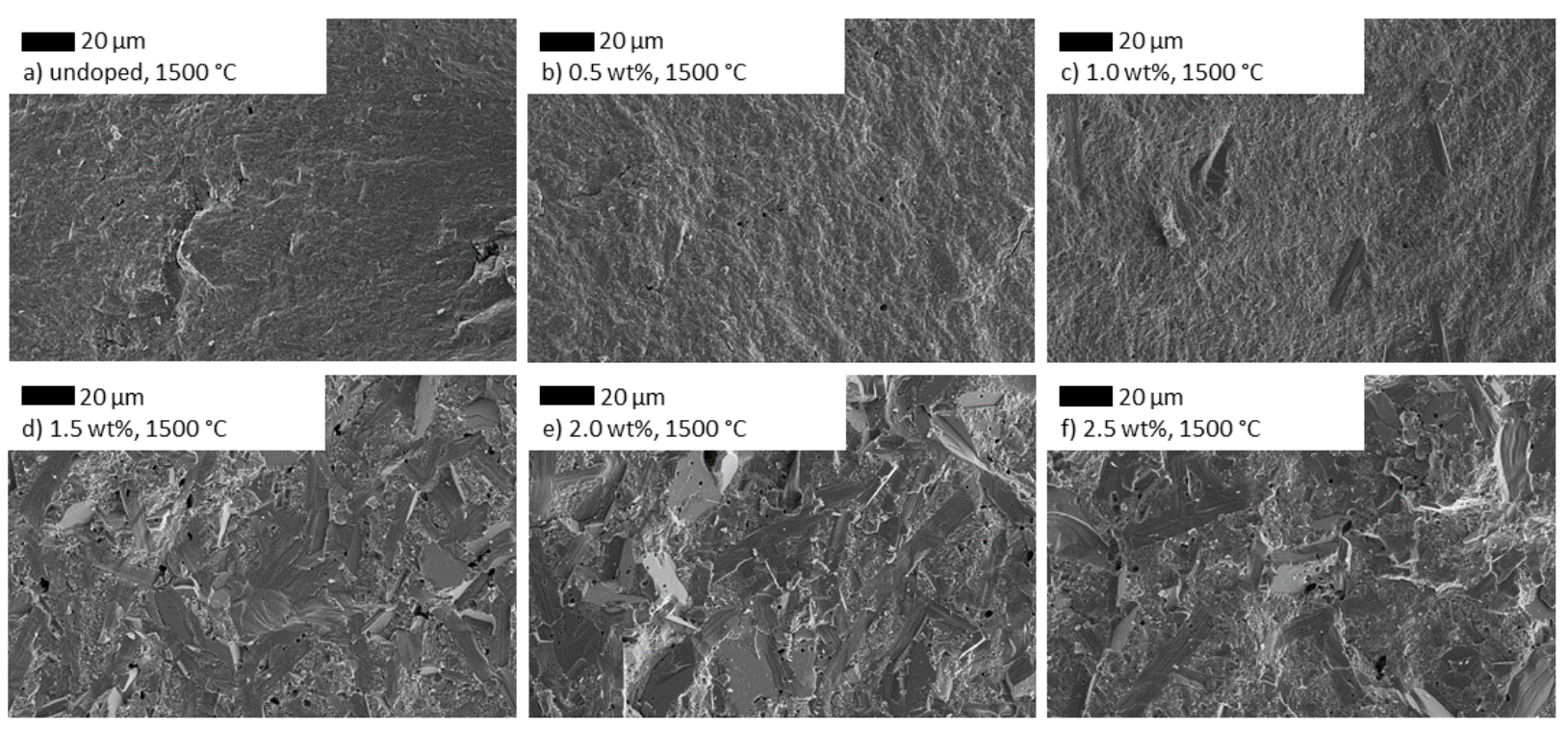

Figure 8. SEM images of Na- $\beta^{\prime \prime}$-alumina samples doped with different amounts of $\mathrm{TiO}_{2}(\mathbf{b}-\mathbf{f})$ in comparison to an undoped sample (a). The images were rearranged and reprinted with permission from Dirksen et al. [13].

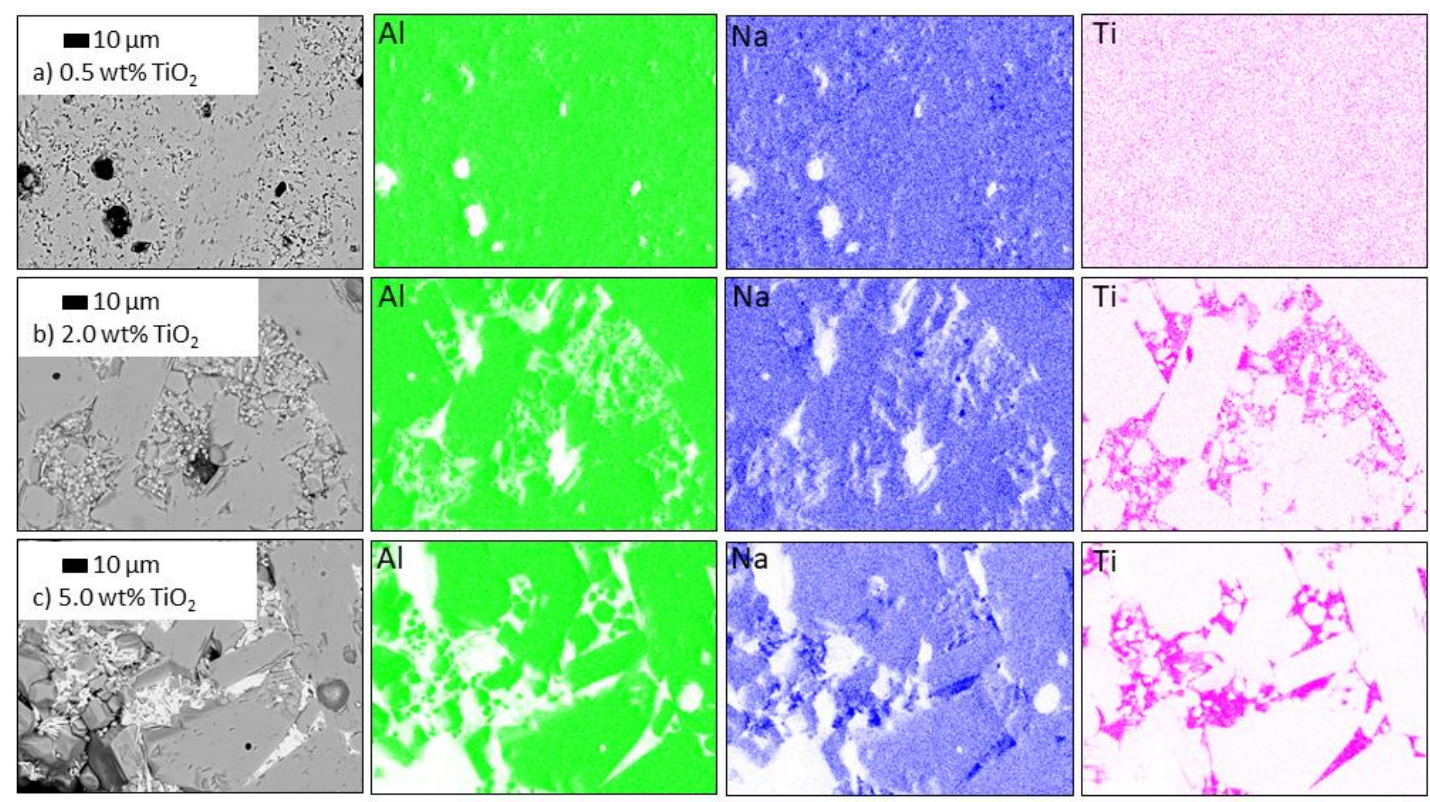

Figure 9. EDX mapping and backscattering SEM images of $\mathrm{TiO}_{2}$-doped, polished $\mathrm{Na}$ - $\beta^{\prime \prime}$-alumina samples (sintered at $1600{ }^{\circ} \mathrm{C}$ ). (a) $0.0 \mathrm{wt} \% \mathrm{TiO}_{2}$ (b) $2.0 \mathrm{wt} \% \mathrm{TiO}_{2}$ (c) $5.0 \mathrm{wt} \% \mathrm{TiO}_{2}$. Al is labeled green; $\mathrm{Na}$ is labeled blue; $\mathrm{Ti}$ is labeled pink. 


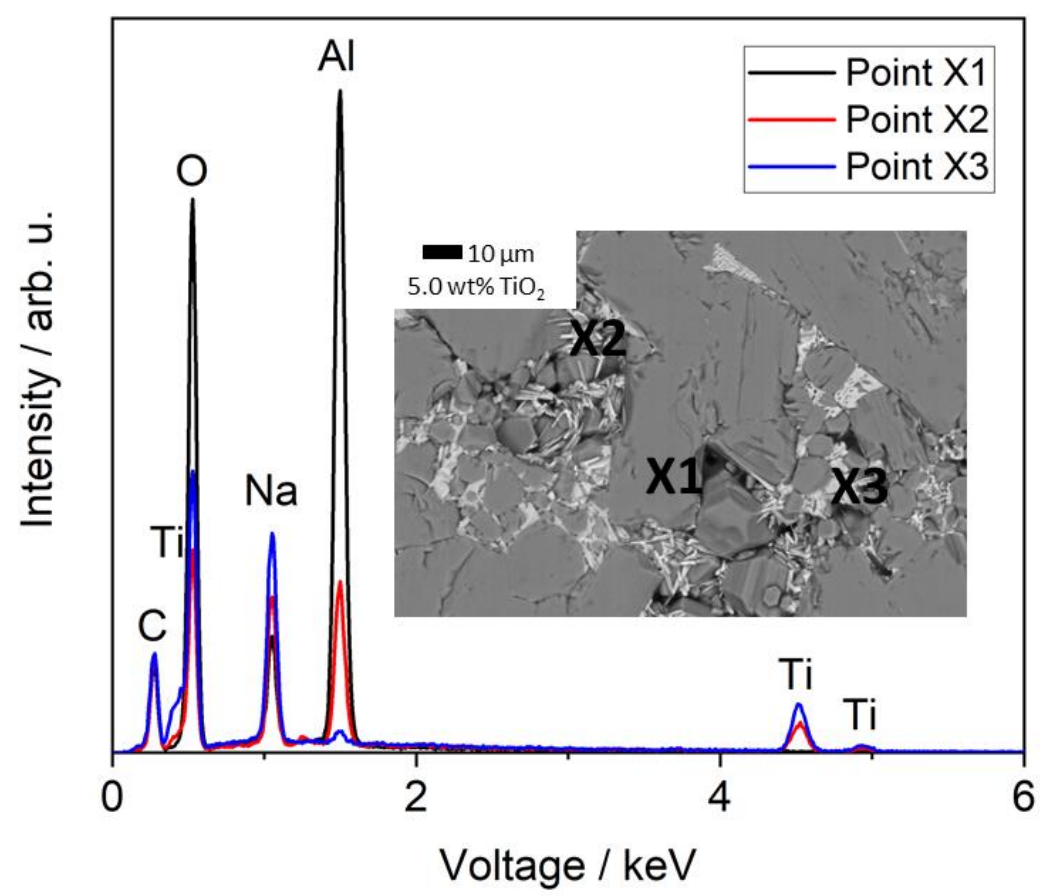

Figure 10. EDX point analysis of a Na- $\beta^{\prime \prime}$-alumina sample doped with $5.0 \mathrm{wt} \% \mathrm{TiO}_{2}$ (sintered at $1600{ }^{\circ} \mathrm{C}$ ). The measuring points are marked in the backscattering-SEM image.

A subsequent spot analysis of the sample doped with $5.0 \mathrm{wt} \% \mathrm{TiO}_{2}$ (Figure 10) confirmed a different chemical composition of the bright appearing sections. Point $\mathrm{X} 2$ $\left(\mathrm{Na}_{3.4} \mathrm{Al}_{3.9} \mathrm{Ti}_{4.2} \mathrm{O}_{16}\right)$ gave a characteristic $\mathrm{Al}$ signal, while point $\mathrm{X} 3\left(\mathrm{Na}_{2.0} \mathrm{Al}_{0.1} \mathrm{Ti}_{3.0} \mathrm{O}_{7}\right)$ displays only signals of $\mathrm{Ti}, \mathrm{Na}$, and $\mathrm{O}$. The small $\mathrm{Al}$ peak is most likely caused by the surrounding area of darker grains. It should be mentioned that areas with the composition of $\mathrm{X} 3$ are more often than those similar to $\mathrm{X} 2$. Point $\mathrm{X} 1\left(\mathrm{Na}_{1.63} \mathrm{Al}_{10.8} \mathrm{O}_{17}\right)$ is directly placed on a dark grain, which shows the typical composition of pure Na- $\beta^{\prime \prime}$-alumina but no Ti. The results strongly indicate that Ti-ions are not replacing Al-ions within the $\mathrm{Na}-\beta^{\prime \prime}$-alumina crystal structure but are located in secondary phases. This postulate is supported by an unchanged lattice constant for Na- $\beta^{\prime \prime}$-alumina despite $\mathrm{TiO}_{2}$ doping. Furthermore, the strong influence of $\mathrm{TiO}_{2}$ doping on the microstructure and densification of $\mathrm{Na}-\beta^{\prime \prime}$-alumina, which is shown in this and previous studies $[18,21,23]$, indicates a liquid-assisted sintering process, caused by substances such as $\mathrm{NaLiTi}_{3} \mathrm{O}_{7}$ or $\mathrm{Na}_{1.97} \mathrm{Al}_{1.82} \mathrm{Ti}_{6.15} \mathrm{O}_{16}$ (melting point: $1300{ }^{\circ} \mathrm{C}$ [35]). The chemical composition measured by EDX does not exactly fit the phases identified in the XRD patterns, which hints toward a non-stoichiometric mix of compounds. Furthermore, Li cannot be detected via EDX due to its small atomic number.

\subsubsection{Influence of $\mathrm{Mn}_{3} \mathrm{O}_{4}$ Doping on the Microstructure}

The influence of $\mathrm{Mn}_{3} \mathrm{O}_{4}$ doping on $\mathrm{Na}-\beta^{\prime \prime}$-alumina strongly differs from $\mathrm{TiO}_{2}$ doping. The microstructure of samples doped with $1.0 \mathrm{wt} \% \mathrm{Mn}_{3} \mathrm{O}_{4}$ and sintered at $1500{ }^{\circ} \mathrm{C}$ or $1600^{\circ} \mathrm{C}$ predominantly consist of small grains, while sintering at $1700{ }^{\circ} \mathrm{C}$ results in excessive grain growth. Higher doping amounts do not promote the formation of large grains (Figure $11 \mathrm{a}, \mathrm{d}-\mathrm{f}$ ) at temperatures of $1600{ }^{\circ} \mathrm{C}$. Since undoped Na- $\beta^{\prime \prime}$-alumina started excessive grain growth at $1600^{\circ} \mathrm{C}, \mathrm{Mn}_{3} \mathrm{O}_{4}$ suppresses the grain growth of $\mathrm{Na}-\beta^{\prime \prime}$-alumina. The EDX mapping of a $\mathrm{Mn}_{3} \mathrm{O}_{4}$-doped sample, displayed in Figure 12, confirms an even distribution of Mn. 


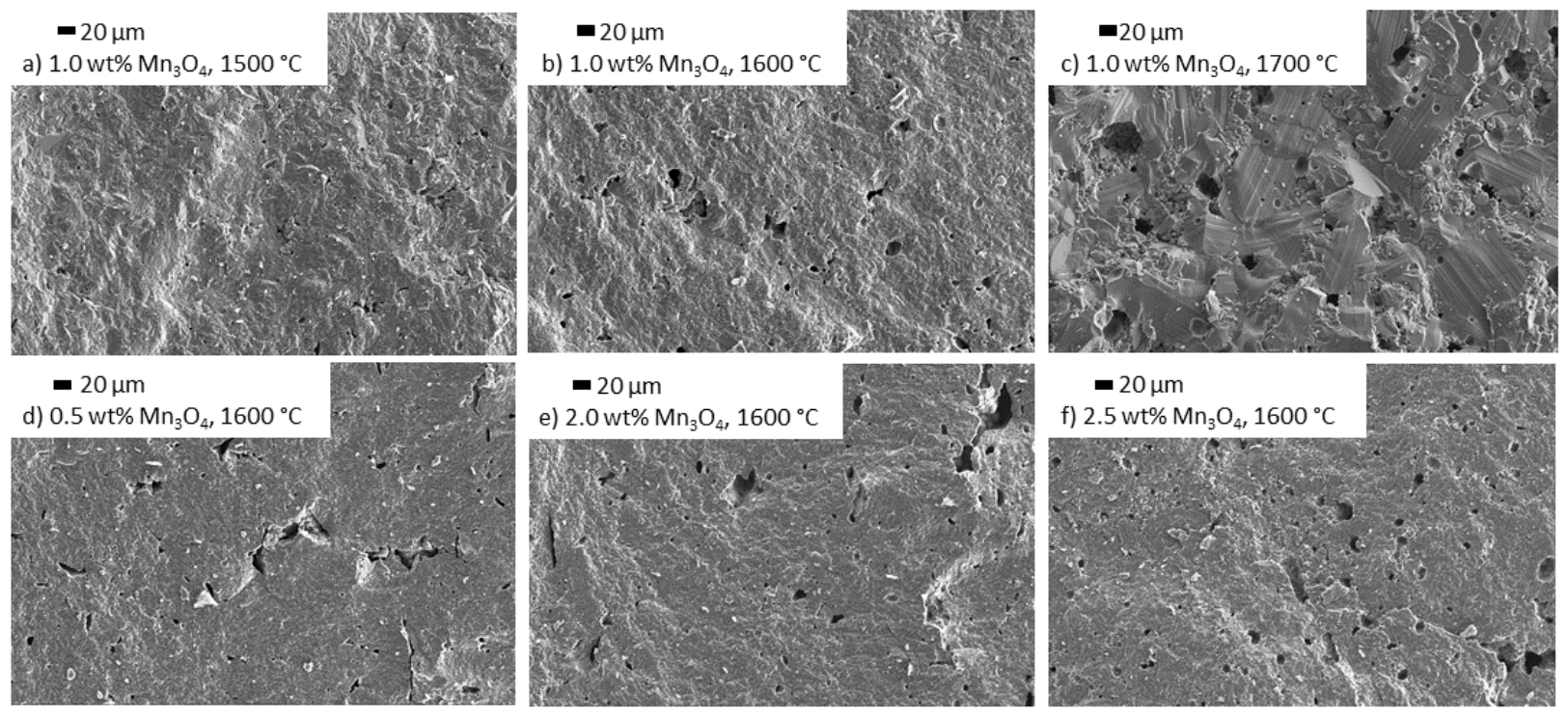

Figure 11. SEM images of Na- $\beta^{\prime \prime}$-alumina samples sintered at $1500{ }^{\circ} \mathrm{C}, 1600^{\circ} \mathrm{C}$, or $1700{ }^{\circ} \mathrm{C}$, doped with different amounts of $\mathrm{Mn}_{3} \mathrm{O}_{4}(\mathbf{b}-\mathbf{f})$ in comparison to an undoped sample (a).

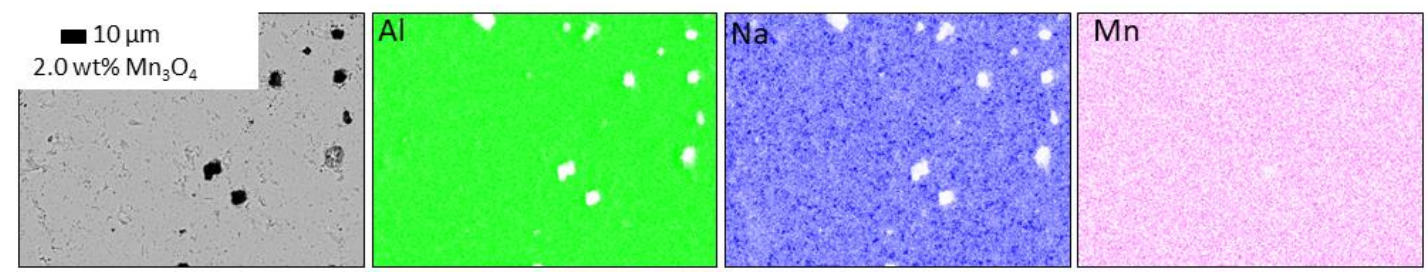

Figure 12. EDX mapping and backscattering SEM image of $\mathrm{Mn}_{3} \mathrm{O}_{4}$-doped, polished $\mathrm{Na}$ - $\beta^{\prime \prime}$-alumina samples (sintered at $\left.1600^{\circ} \mathrm{C}\right)$. $\mathrm{Al}$ is labeled green; $\mathrm{Na}$ is labeled blue; $\mathrm{Mn}$ is labeled pink.

\subsubsection{Influence of $\mathrm{NiO}$ Doping on the Microstructure}

$1.0 \mathrm{wt} \% \mathrm{NiO}$ doped $\mathrm{Na}-\beta^{\prime \prime}$-alumina shows a microstructure with fine grains and only occasional large grains for all tested sintering temperatures (Figure 13a-c). The variation of the $\mathrm{NiO}$ doping amount at a fixed sintering temperature of $1600{ }^{\circ} \mathrm{C}$ (Figure $13 \mathrm{a}, \mathrm{d}-\mathrm{f}$ ) shows that $0.5 \mathrm{wt} \%$ of doping does not prevent excess grain growth. Samples doped with $2.0 \mathrm{wt} \%$ and $2.5 \mathrm{wt} \%$ show a fine-grained microstructure with a few scattered large grains. The EDX mapping (Figure 14) shows an even distribution of Ni over the whole sample. The isolated white dots visible in the backscattering electron SEM are caused by $\mathrm{ZrO}_{2}$ particles, which remained from the milling process.

Compared to this work, Zhu et al. [20] found different effects for Na- $\beta^{\prime \prime}$-alumina electrolytes doped with $\mathrm{NiO}$. They observed increased densification of doped samples, which could not be confirmed. Most certainly, those differences can be explained by the different manufacturing processes. Zhu et al. added the dopant before calcining, while this work added the dopant after calcining. Moreover, Zhu et al. sintered their samples as low as $1400{ }^{\circ} \mathrm{C}$ for $2 \mathrm{~h}$ instead of choosing higher temperatures for a time of $0.5 \mathrm{~h}$.

It can be stated that the addition of $\mathrm{Mn}_{3} \mathrm{O}_{4}$ and $\mathrm{NiO}$ suppresses the formation of large grains. Neither $\mathrm{Mn}_{3} \mathrm{O}_{4}$ nor $\mathrm{NiO}$ doping caused any formation of detectable secondary phases in XRD measurements, while the lattice parameters changed. This indicates incorporation of $\mathrm{Mn}$ and $\mathrm{Ni}$ into the crystal lattice of $\mathrm{Na}-\beta^{\prime \prime}$-alumina. Furthermore, EDX measurements and backscattering SEM did not reveal any secondary phases related to $\mathrm{Mn}_{3} \mathrm{O}_{4} / \mathrm{NiO}$ doping. Therefore, it is likely, that $\mathrm{Mn}$ - and $\mathrm{Ni}$-ions replace Al-ions within the spinel block as assumed by previous researchers $[25,36]$. 

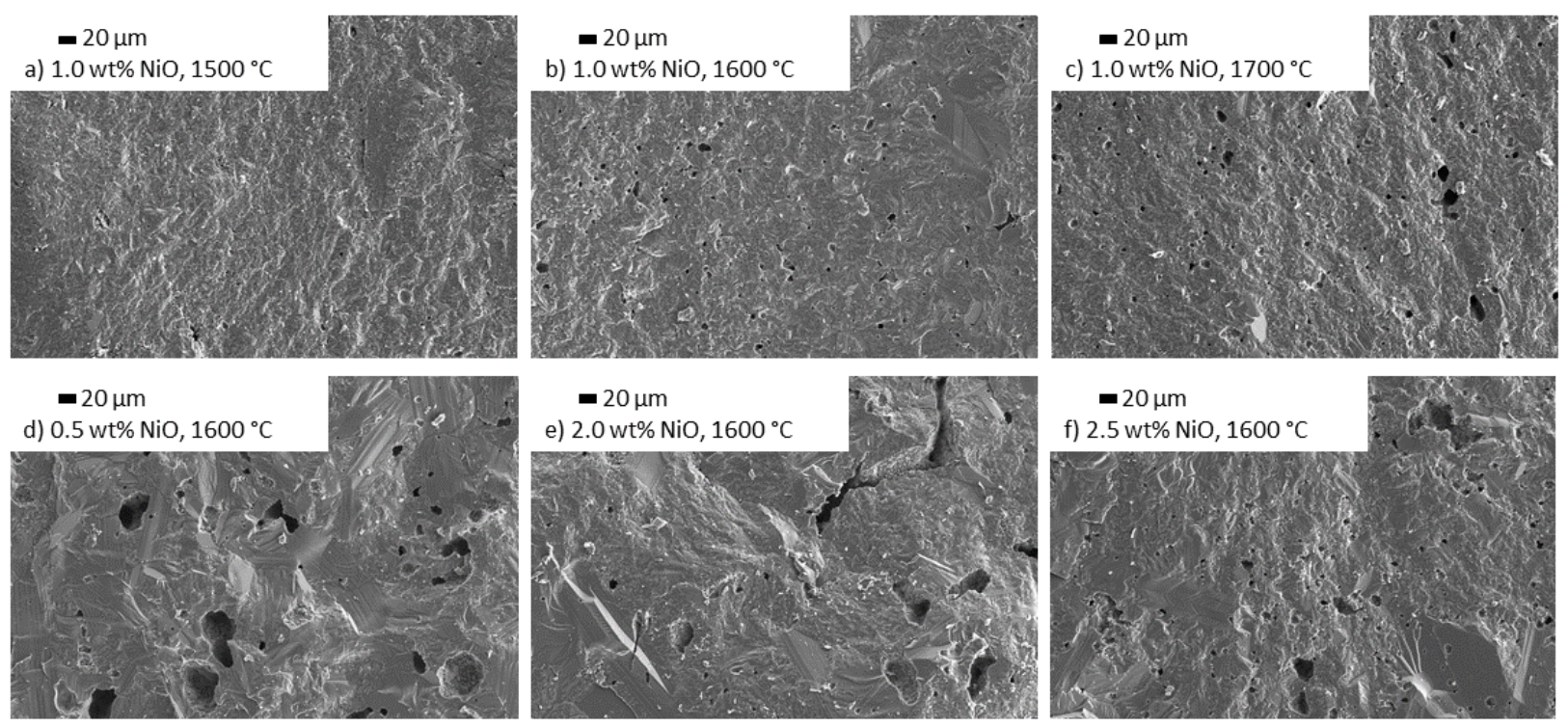

Figure 13. SEM images of Na- $\beta^{\prime \prime}$-alumina samples sintered at $1500{ }^{\circ} \mathrm{C}, 1600^{\circ} \mathrm{C}$, or $1700{ }^{\circ} \mathrm{C}$, doped with different amounts of $\mathrm{NiO}(\mathbf{b}-\mathbf{f})$ in comparison to an undoped sample (a).
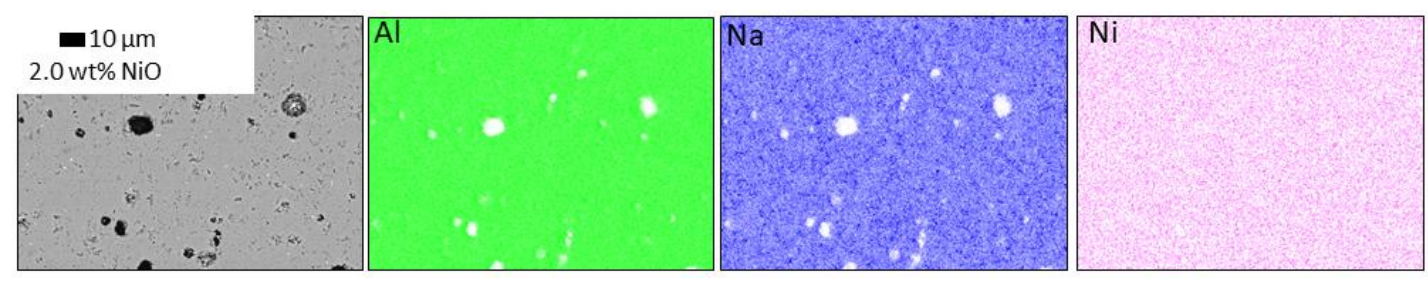

Figure 14. EDX mapping and backscattering SEM image of NiO-doped, polished Na- $\beta^{\prime \prime}$-alumina samples (sintered at $\left.1600{ }^{\circ} \mathrm{C}\right)$. $\mathrm{Al}$ is labeled green; $\mathrm{Na}$ is labeled blue; $\mathrm{Ni}$ is labeled pink.

\subsection{Fracture Strength Analysis}

The fracture strength is an essential material property of Na- $\beta^{\prime \prime}$-alumina electrolytes. It limits the dimensions of an electrolyte that are required to withstanding the mechanical stresses occurring in an operating electrochemical cell. Figure 15 shows comparatively the characteristic fracture strengths $\sigma_{0}$ for a failure probability of $63.2 \%$. Tables S1-S3 present the exact values and additionally the distribution parameter $\mathrm{m}$ from data evaluation according to Weibull statistics.

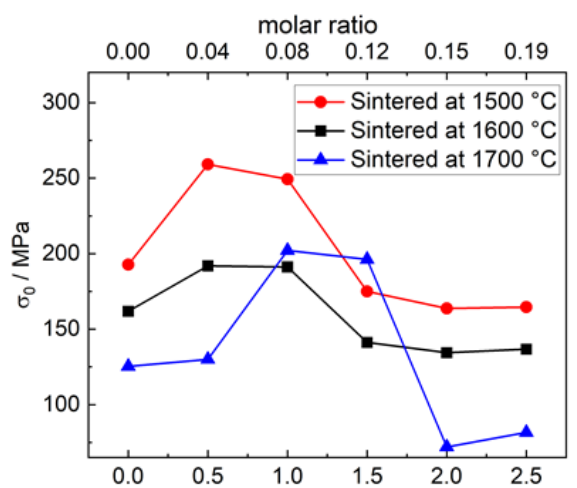

(a) $\mathrm{TiO}_{2}$ doping amount $/ \mathrm{wt} \%$

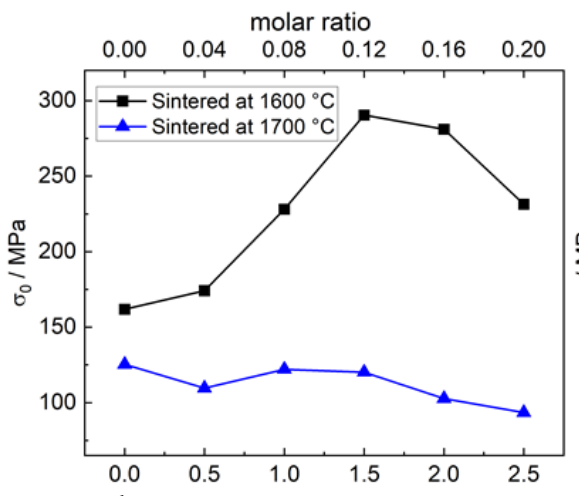

(b) $\mathrm{Mn}_{3} \mathrm{O}_{4}$ doping amount $/ \mathrm{wt} \%$

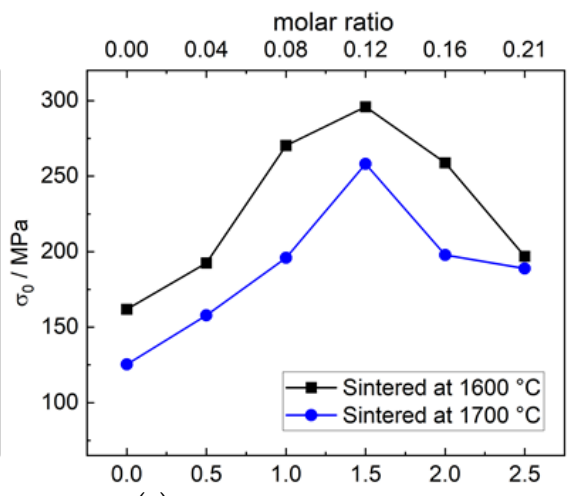

(c) $\mathrm{NiO}$ doping amount $/ \mathrm{wt} \%$

Figure 15. (a) Characteristic fracture strength $\sigma_{0}$ of $\mathrm{TiO}_{2}$-doped $\mathrm{Na}$ - $\beta^{\prime \prime}$-alumina. The results of $\mathrm{TiO}_{2}$-doped samples and sintering temperatures of $1500{ }^{\circ} \mathrm{C}$ and $1600{ }^{\circ} \mathrm{C}$ are reprinted with permission from Dirksen et al. [13]. (b) Characteristic fracture strength $\sigma_{0}$ of $\mathrm{Mn}_{3} \mathrm{O}_{4}$-doped $\mathrm{Na}-\beta^{\prime \prime}$-alumina. (c) Characteristic fracture strength $\sigma_{0}$ of NiO-doped Na- $\beta^{\prime \prime}$-alumina. 


\subsubsection{Influence of $\mathrm{TiO}_{2}$ Doping on the Fracture Strength}

For undoped samples, a clear decrease of characteristic fracture strength was found for increasing sintering temperatures. The $\sigma_{0}$ value of samples sintered at $1500{ }^{\circ} \mathrm{C}$ was $193 \mathrm{MPa}$, while sintering at $1700{ }^{\circ} \mathrm{C}$ decreased $\sigma_{0}$ to $125 \mathrm{MPa}$. The reason for this decrease in fracture strength can be found in the increased porosity and grain size with rising sintering temperature.

Small amounts of $\mathrm{TiO}_{2}$ doping increase the characteristic fracture strength of $\mathrm{Na}-\beta^{\prime \prime}$ alumina electrolytes regardless of the sintering temperature. Doping of $0.5 \mathrm{wt} \% \mathrm{TiO}_{2}$ and a sintering temperature of $1500{ }^{\circ} \mathrm{C}$ led to the maximum characteristic fracture strength of $259 \mathrm{MPa}$. Higher doping amounts than $1.0 \mathrm{wt} \% \mathrm{TiO}_{2}$ causes an abrupt decrease of the characteristic fracture strength. This observation corresponds well with the SEM images, which prove extensive grain growth. At higher sintering temperatures, the fracture strength $\sigma_{0}$ follows the same trend as the relative density. It indicates that porosity becomes the most impactful factor. Chen et al. [24] found a maximum fracture strength of $230 \mathrm{MPa}$ at a similar doping amount of $0.5 \mathrm{wt} \% \mathrm{TiO}_{2}$.

\subsubsection{Influence of $\mathrm{Mn}_{3} \mathrm{O}_{4}$ Doping on the Fracture Strength}

Compared to $\mathrm{TiO}_{2}$ - and NiO-doped samples, the distribution of fracture strength of $\mathrm{Mn}_{3} \mathrm{O}_{4}$-doped samples appears different. At sintering temperatures of $1600{ }^{\circ} \mathrm{C}$, the characteristic fracture strength increases from $162 \mathrm{MPa}$ to $290 \mathrm{MPa}$ by doping with $1.5 \mathrm{wt} \%$ $\mathrm{Mn}_{3} \mathrm{O}_{4}$. At a sintering temperature of $1700^{\circ} \mathrm{C}$, no further upward trend is observed. Those results correspond well with the SEM images in the section "3.3 SEM and EDX analysis". While $\mathrm{Mn}_{3} \mathrm{O}_{4}$ doping was able to suppress extensive grain growth at $1600{ }^{\circ} \mathrm{C}$, temperatures of $1700{ }^{\circ} \mathrm{C}$ resulted in excessive grain growth.

\subsubsection{Influence of NiO Doping on the Fracture Strength}

$\mathrm{NiO}$ is the most efficient dopant in terms of increasing fracture strength. Doping with $1.5 \mathrm{wt} \% \mathrm{NiO}$ increased the characteristic fracture strength from $162 \mathrm{MPa}$ to $296 \mathrm{MPa}$ after sintering at $1600{ }^{\circ} \mathrm{C}$, because it prevents extensive grain growth. The impact of Ni-ion incorporation into the crystal lattice on the fracture strength is not clear yet. However, it seems likely that very high doping amounts can destabilize the crystal lattice. Zhu et al. [20] also doped Li-stabilized $\mathrm{Na}-\beta^{\prime \prime}$-alumina with $\mathrm{NiO}$ and observed the same fracture strength maximum at $296 \mathrm{MPa}$, but at a doping amount of $0.25 \mathrm{wt} \%$. A reason for the different results might be the usage of different reactants. Lu et al. used $\alpha-\mathrm{Al}_{2} \mathrm{O}_{3}$ and $\mathrm{Na}_{2} \mathrm{C}_{2} \mathrm{O}_{4}$, while $\mathrm{AlO}(\mathrm{OH})$ and $\mathrm{Na}_{2} \mathrm{CO}_{3}$ were used in this work. Especially the $\mathrm{Al}$ source influences the Na- $\beta^{\prime \prime}$-alumina ceramic's fracture strength $[14,37]$.

\subsection{Ionic Conductivity Analysis}

High ionic conductivity of the electrolyte is crucial for a highly efficient cell system. Several factors are influential for the ionic conductivity of polycrystalline Na- $\beta^{\prime \prime}$-alumina electrolytes. First, grain size and extensive grain growth play an important role [13]. Large grains decrease the grain boundary resistivity since fewer grain boundaries have to be passed. Additionally, large, anisotropic, and 2D-conductive grains lower the tortuosity and therefore shorten the ion pathway, which decreases the effective resistance [38]. The severity of anisotropy was visible in the intensity of the reflexes 006 . Second, the porosity and the related density of the solid electrolyte influence ionic conductivity. An increasing porosity extends the pathway for the sodium ions, and the ionic conductivity decreases. Third, the intrinsic conductivity of the $\mathrm{Na}-\beta^{\prime \prime}$-alumina grains possibly changed due to the incorporation of foreign ions into the lattice can have an impact on the ionic conductivity. Fourth, the phase content of the highly conductive Na- $\beta^{\prime \prime}$-alumina within the electrolyte is of great importance. Due to the complex phase formation process of poly crystalline Na$\beta^{\prime \prime}$-alumina, a mixture of $\beta^{\prime \prime}$ and $\beta$-alumina as well as some secondary phases will always be present in the electrolyte. Accordingly, the Na- $\beta^{\prime \prime}$-alumina content and the sensitive process for electrolyte production needs to be optimized. Figure $\mathrm{S} 1$ shows representative 
Nyquist plots from impedance spectroscopy measurements and the corresponding fits used to determine $R_{b}$ and $R_{g b}$.

\subsubsection{Influence of $\mathrm{TiO}_{2}$ Doping on the Ionic Conductivity}

Figure 16 displays the overall ionic conductivity at $30{ }^{\circ} \mathrm{C}$ of the different samples. For undoped electrolyte samples, the conductivity increases from $0.15 \mathrm{~S} \mathrm{~cm}^{-1}$ over $0.21 \mathrm{~S} \mathrm{~cm}^{-1}$ to $0.25 \mathrm{~S} \mathrm{~cm}^{-1}$ with an increasing sintering temperature from $1500{ }^{\circ} \mathrm{C}$ over $1600^{\circ} \mathrm{C}$ to $1700{ }^{\circ} \mathrm{C}$. This increase can be addressed to the increasing grain size since the phase content of the sample stays nearly constant (see XRD results in Section 3.1). The porosity, which increases due to the higher sintering temperature (Figure 6), is not high enough to counter the effect of excessive grain growth. The grain growth is also causal for the decrease of characteristic fracture strength discussed in Section 3.4.
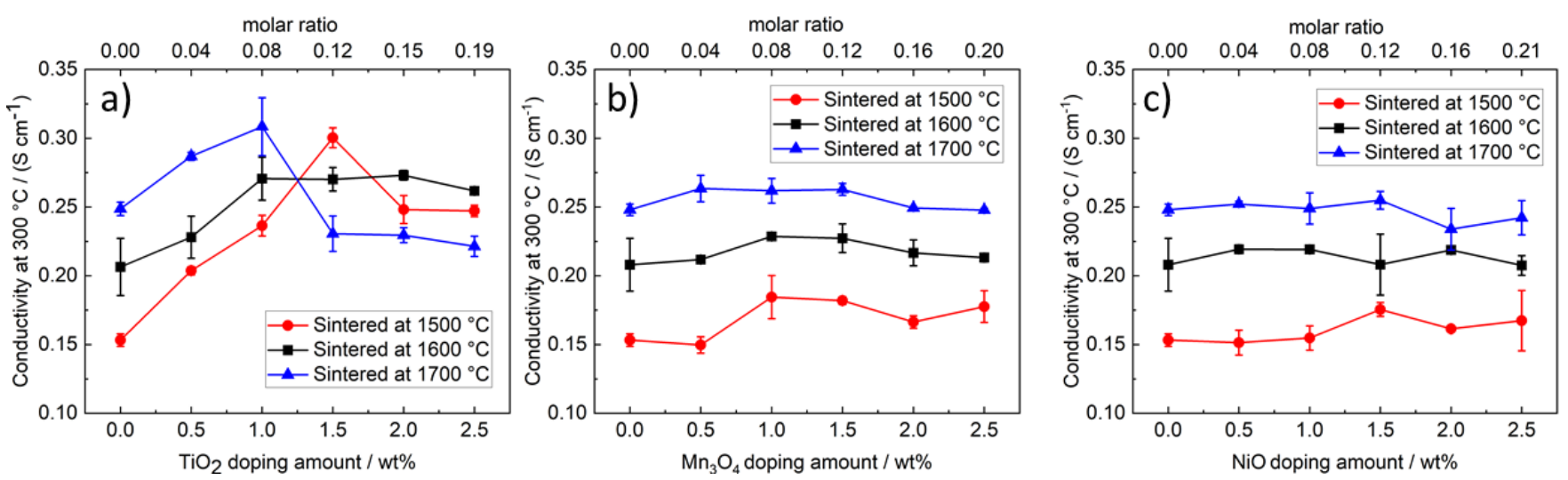

Figure 16. Ionic conductivity at $300{ }^{\circ} \mathrm{C}$ of differently doped and sintered $\mathrm{Na}-\beta^{\prime \prime}$-alumina samples. (a) $\mathrm{TiO}_{2}$-doped $\mathrm{Na}-\beta^{\prime \prime}-$ alumina; the results of $\mathrm{TiO}_{2}$-doped samples sintered at temperatures of $1500{ }^{\circ} \mathrm{C}$ and $1600{ }^{\circ} \mathrm{C}$ are reprinted with permission from Dirksen et al. [13] (b) $\mathrm{Mn}_{3} \mathrm{O}_{4}$-doped $\mathrm{Na}-\beta^{\prime \prime}$-alumina; (c) $\mathrm{NiO}$-doped $\mathrm{Na}$ - $\beta^{\prime \prime}$-alumina.

The ionic conductivity of the electrolyte samples doped with $\mathrm{TiO}_{2}$ is displayed in Figure 16a. Next to the sintering temperature, the $\mathrm{TiO}_{2}$ doping amount influences the measured conductivity enormously. At sintering temperatures of $1500^{\circ} \mathrm{C}$, the ionic conductivity is increased from $0.15 \mathrm{~S} \mathrm{~cm}^{-1}$ to $0.30 \mathrm{~S} \mathrm{~cm}^{-1}$ by adding $1.5 \mathrm{wt} \% \mathrm{TiO}_{2}$. SEM images show that in between $1.0 \mathrm{wt} \%$ and $1.5 \mathrm{wt} \%$ of dopant and at a sintering temperature of $1500{ }^{\circ} \mathrm{C}$, the excessive grain growth takes place. The grain growth leads to an increase in conductivity while the fracture strength decreases. A further increase of the $\mathrm{TiO}_{2}$ doping amount at $1500{ }^{\circ} \mathrm{C}$ results in a decreasing conductivity. The formation of pores and the corresponding decrease of material density (Figure 6) obviously compensates for the positive effect of grain growth. The conductivity is lowered from approximately $0.30 \mathrm{~S} \mathrm{~cm}^{-1}$ to $0.25 \mathrm{~S} \mathrm{~cm}^{-1}$.

Independently from the doping level, at sintering temperatures of $1600{ }^{\circ} \mathrm{C}$ and $1700^{\circ} \mathrm{C}$, an excessive grain growth is present, which is mirrored in high ionic conductivities.

$\mathrm{TiO}_{2}$ doping with $1.0 \mathrm{wt} \%$ results in the highest conductivities and the highest material densities.

The influence of the Na- $\beta^{\prime \prime}$-alumina phase content on the ionic conductivity is low since the phase content changes only marginally at different temperatures and doping amounts (Table 1). Ti-ions are not incorporated into the Na- $\beta^{\prime \prime}$-alumina crystal lattice; therefore, a change of the intrinsic conductivity of $\mathrm{Na}-\beta^{\prime \prime}$-alumina is not expected. $\mathrm{Na}$-ion depletion of the Na- $\beta^{\prime \prime}$-alumina phase due to the formation of Na and Ti secondary phases might have a minimal influence. However, a massive depletion seems unlikely because all tested samples contained a small yet notable amount of Na-rich $\mathrm{NaAlO}_{2}$.

The specific grain boundary resistances $R_{\mathrm{sgb}}$ (see Figure 17a) are in good agreement with the observed microstructure: The specific grain boundary resistance of undoped samples, sintered at $1500{ }^{\circ} \mathrm{C}$, shrinks from $0.38 \Omega \mathrm{cm}$ to $0.16 \Omega \mathrm{cm}$ for samples sintered at 
$1700{ }^{\circ} \mathrm{C}$. All samples with a microstructure shaped by large grains have a specific grain boundary resistance of less than $0.25 \Omega \mathrm{cm}$. Samples with finer grains $(0.0$ and $0.5 \mathrm{wt} \%$ $\mathrm{TiO}_{2}$ doping/sintered at $1500{ }^{\circ} \mathrm{C}$ ) show resistance of $0.38 \Omega \mathrm{cm}$ and $0.34 \Omega \mathrm{cm}$ because $\mathrm{Na}$-ions must cross more grain boundaries. Potentially, impedance spectroscopy can be used to get an impression of the microstructure of Na- $\beta^{\prime \prime}$-alumina electrolytes. It is already done for other materials $[39,40]$.
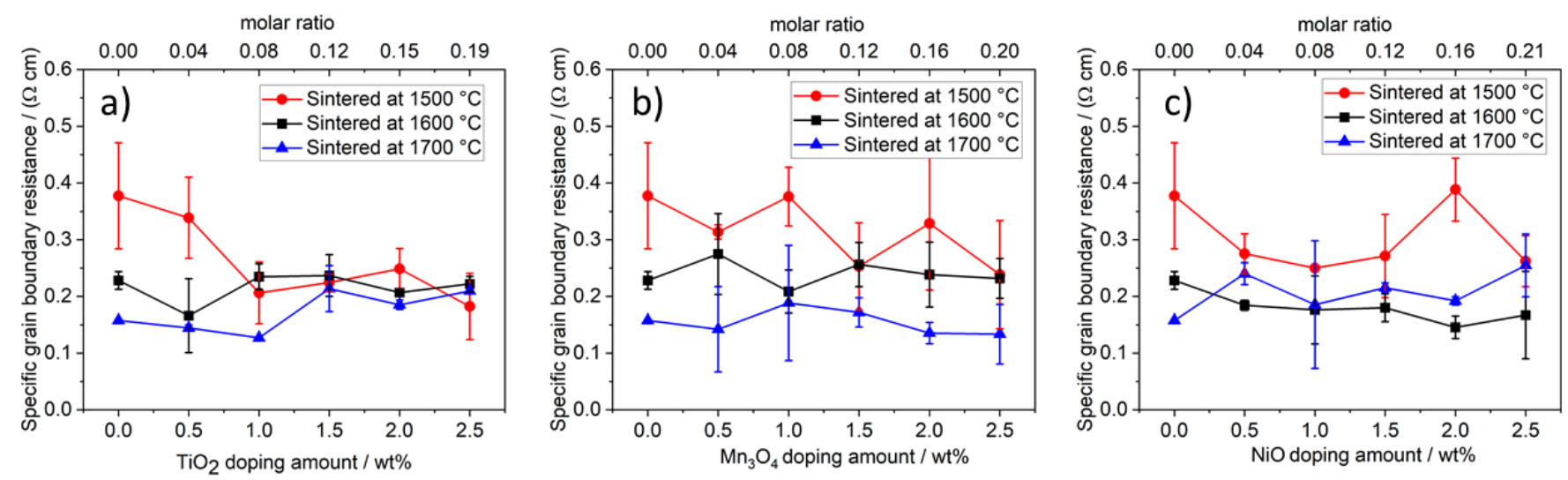

Figure 17. Specific grain boundary resistance of $\mathrm{Na}-\beta^{\prime \prime}$-alumina samples. (a) $\mathrm{TiO}_{2}$-doped $\mathrm{Na}-\beta^{\prime \prime}$-alumina; (b) $\mathrm{Mn}_{3} \mathrm{O}_{4}$-doped $\mathrm{Na}-\beta^{\prime \prime}$-alumina; (c) NiO-doped $\mathrm{Na}-\beta^{\prime \prime}$-alumina.

\subsubsection{Influence of $\mathrm{Mn}_{3} \mathrm{O}_{4}$ and $\mathrm{NiO}$ Doping on the Ionic Conductivity}

The influence of $\mathrm{Mn}_{3} \mathrm{O}_{4}$ and $\mathrm{NiO}$ doping on the overall ionic conductivity (Figure 16) of Na- $\beta^{\prime \prime}$-alumina electrolytes was much lower compared to that of $\mathrm{TiO}_{2}$. Only a negligible impact was detected. This observation is remarkable because the grain size and thereby the characteristic fracture strength was lowered by those dopants. Therefore, lower conductivities should be expected. Furthermore, the relative density of the Na- $\beta^{\prime \prime}$-alumina samples was only slightly influenced by doping. Hence, it seems likely that the intrinsic conductivity of the Na- $\beta^{\prime \prime}$-alumina crystals changes due to the incorporation of $\mathrm{Mn}$ - or Ni-ions. Boilot et al. [36] assume that $\mathrm{M}^{2+}$ ions like $\mathrm{Mn}^{2+}$ and $\mathrm{Ni}^{2+}$, which replace $\mathrm{Al}^{3+}$, can reduce the number of interstitial oxygen ions because fewer oxygen ions are needed to achieve electric neutrality. The reduced number of interstitial oxygen ions is considered to enhance the diffusion of Na-ions within the ion conductive plane.

The specific grain boundary resistance of $\mathrm{Mn}_{3} \mathrm{O}_{4}$-doped samples (Figure 17b) decreases with higher sintering temperatures, while the doping amount shows only little influence. NiO-doped samples behave similarly but show faintly lower grain boundary resistance at a sintering temperature of $1600{ }^{\circ} \mathrm{C}$.

\section{Conclusions}

Li-stabilized $\mathrm{Na}-\beta^{\prime \prime}$-alumina powder was doped with three different $3 \mathrm{~d}$ transition metal oxides $\left(\mathrm{TiO}_{2}, \mathrm{Mn}_{3} \mathrm{O}_{4}\right.$, and $\left.\mathrm{NiO}\right)$, granulated, pressed, and sintered at different temperatures. For the first time, the mechanism from $\mathrm{TiO}_{2}$ doping of $\mathrm{Li}$-stabilized $\mathrm{Na}-\beta^{\prime \prime}$-alumina was clarified and understood. It was found that $\mathrm{TiO}_{2}$ doping promotes the formation of secondary phases such as $\mathrm{NaLiTi}_{3} \mathrm{O}_{7}$ and $\mathrm{Na}_{1.97} \mathrm{Al}_{1.82} \mathrm{Ti}_{6.15} \mathrm{O}_{16}$. This assumption was supported by results from SEM-EDX measurements, which clearly proved the absence of $\mathrm{Ti}$ inside the Na- $\beta^{\prime \prime}$-alumina grains. Since the melting point of $\mathrm{Na}_{2} \mathrm{Al}_{2} \mathrm{Ti}_{6} \mathrm{O}_{16}$ amounts to $1300{ }^{\circ} \mathrm{C}$ [35], liquid-assisted sintering can be assumed. This assumption was confirmed by the successful synthesis of highly conductive electrolytes $\left(0.30 \mathrm{~S} \mathrm{~cm}^{-1}\right.$ at $\left.300{ }^{\circ} \mathrm{C}\right)$ and the formation of a coarse-grained microstructure even at a very low sintering temperature of only $1500{ }^{\circ} \mathrm{C}$. It is not clear yet to what extent the secondary phases can influence the long-term stability of $\mathrm{Na}-\beta^{\prime \prime}$-alumina regarding electrochemical stability and dendrites formation. 
For $\mathrm{Mn}_{3} \mathrm{O}_{4}$ - and NiO-doped Na- $\beta^{\prime \prime}$-alumina, no formation of secondary phases and according liquid-assisted sintering was observed. Only minor changes in the ionic conductivity were measured independently from the doping level. SEM-EDX and XRD measurements indicated that $\mathrm{Mn}$ - and Ni-ions occupy the Al-positions in the lattice of the $\mathrm{Na}-\beta^{\prime \prime}$-alumina crystals, while the Ti-ions are located in secondary phases.

All three dopants increased the characteristic fracture strength of the electrolytes. The enhancement was assigned to changes in the microstructure. The addition of $1.5 \mathrm{wt} \% \mathrm{NiO}$ increased the characteristic fracture strength from 162 to $296 \mathrm{MPa}$ (at sintering temperature of $\left.1600^{\circ} \mathrm{C}\right)$.

From the comparative studies, it can be summarized that $\mathrm{TiO}_{2}$ is the dopant that affects the Na- $\beta^{\prime \prime}$-alumina properties most intensively. It has the potential to reduce the sintering temperature, increase fracture strength, and enhance ionic conductivity. A good balance of those parameters was found at a doping amount of $1.0 \mathrm{wt} \% \mathrm{TiO}_{2}$ and a sintering temperature of $1500{ }^{\circ} \mathrm{C}$. The low sintering temperature decreases the energy consumption of the manufacturing process. Simultaneously, the characteristic fracture strength was increased from 193 to $249 \mathrm{MPa}$. The ionic conductivity at $300{ }^{\circ} \mathrm{C}$ amounts to $0.22 \mathrm{~S} \mathrm{~cm}^{-1}$ for this material.

The reported results suggest that $3 \mathrm{~d}$ transition metal doping represent an effective method to adjust the electrolyte properties on the one hand and optimize the energy consumption for electrolyte production on the other hand. By targeted doping, the production of thin-walled, stable, and highly conductive $\mathrm{Na}-\beta^{\prime \prime}$-alumina electrolytes for Na-based batteries becomes feasible. Future research will address the mixture of different dopants such as $\mathrm{TiO}_{2}$ and $\mathrm{NiO}$ to evaluate if an even higher characteristic fracture strength can be achieved at low sintering temperatures. Furthermore, tests on $\mathrm{Na} / \mathrm{NiCl}_{2}$-cells in order to test the long-term stability of doped $\mathrm{Na}-\beta^{\prime \prime}$-alumina electrolytes are pending.

Supplementary Materials: The following are available online at https://www.mdpi.com/article/ $10.3390 / \mathrm{ma14185389/s1}$, Figure S1: Nyquist plots of differently doped Na- $\beta^{\prime \prime}$-alumina samples recorded at $300{ }^{\circ} \mathrm{C}$. (a) $1.0 \mathrm{wt} \% \mathrm{TiO}_{2}$ doped (b) $1.0 \mathrm{wt} \% \mathrm{Mn}_{3} \mathrm{O}_{4}$ doped (c) $1.0 \mathrm{wt} \% \mathrm{NiO}$ doped.; Table S1: Characteristic fracture $\sigma_{0}$ and distribution parameter $\mathrm{m}$ of $\mathrm{TiO}_{2}$ doped Na- $\beta^{\prime \prime}$-alumina sintered at temperatures from $1500^{\circ} \mathrm{C}$ to $1700^{\circ} \mathrm{C}$; Table S2: Characteristic fracture $\sigma_{0}$ and distribution parameter $\mathrm{m}$ of $\mathrm{Mn}_{3} \mathrm{O}_{4}$ doped $\mathrm{Na}-\beta^{\prime \prime}$-alumina sintered at temperatures $1600^{\circ} \mathrm{C}$ respectively $1700^{\circ} \mathrm{C}$; Table S3: Characteristic fracture $\sigma_{0}$ and distribution parameter $\mathrm{m}$ of $\mathrm{NiO}$ doped Na- $\beta^{\prime \prime}$-alumina sintered at temperatures $1600^{\circ} \mathrm{C}$ respectively $1700^{\circ} \mathrm{C}$

Author Contributions: Conceptualization, C.L.D., K.S., M.S. (Matthias Schulz), and M.S. (Michael Stelter); methodology, C.L.D., K.S., and M.S. (Matthias Schulz); validation, C.L.D., K.S., M.S. (Matthias Schulz), and M.P.F.; formal analysis, C.L.D. and K.S.; investigation, C.L.D.; resources, K.S., M.S. (Matthias Schulz), and M.S. (Michael Stelter); writing-original draft preparation, C.L.D.; writingreview and editing, C.L.D., K.S., M.S. (Matthias Schulz), M.P.F., and M.S. (Michael Stelter); supervision, C.L.D., K.S., M.S. (Matthias Schulz), and M.S. (Michael Stelter); project administration, C.L.D. and K.S.; funding acquisition, K.S., M.S. (Matthias Schulz), and M.S. (Michael Stelter) All authors have read and agreed to the published version of the manuscript.

Funding: This work was supported by the German Federal Ministry of Education and Research project number (03XP0171A).

Institutional Review Board Statement: Not applicable.

Informed Consent Statement: Not applicable.

Data Availability Statement: The data presented in this study are available on request from the corresponding author.

Conflicts of Interest: The authors declare no conflict of interest. 


\section{References}

1. Wang, Y.; Song, S.; Xu, C.; Hu, N.; Molenda, J.; Lu, L. Development of solid-state electrolytes for sodium-ion battery-A short review. Nano Mater. Sci. 2019, 1, 91-100. [CrossRef]

2. Sudworth, J. The sodium/nickel chloride (ZEBRA) battery. J. Power Sources 2001, 100, 149-163. [CrossRef]

3. Ligon, S.C.; Blugan, G.; Bay, M.-C.; Battaglia, C.; Heinz, M.V.; Graule, T. Performance analysis of $\mathrm{Na}^{-} \beta^{\prime \prime}-\mathrm{Al}_{2} \mathrm{O}_{3} / \mathrm{YSZ}_{\mathrm{S}}$ solid electrolytes produced by conventional sintering and by vapor conversion of $\alpha-\mathrm{Al}_{2} \mathrm{O}_{3} / \mathrm{YSZ}$. Solid State Ion. 2020, 345, 115169. [CrossRef]

4. Agustina, A.I.; Skadell, K.; Dirksen, C.L.; Schulz, M.; Kusumocahyo, S.P. Sol-gel method for synthesis of Li ${ }^{+}$-stabilized Na- $\beta^{\prime \prime}{ }_{-}$ alumina for solid electrolytes in sodium-based batteries. In AIP Conference Proceedings; AIP Publishing LLC.: Melville, NY, USA, 2019; p. 20070. [CrossRef]

5. Butee, S.; Kambale, K.; Firodiya, M. Electrical properties of sodium beta-alumina ceramics synthesized by citrate sol-gel route using glycerine. PAC 2016, 10, 67-72. [CrossRef]

6. Lin, J.; Wen, Z.; Wang, X.; Song, S.; Liu, Y. Mechanochemical synthesis of $\mathrm{Na}-\beta / \beta^{\prime \prime}-\mathrm{Al}_{2} \mathrm{O}_{3}$. J. Solid State Electrochem. 2010, 14, 1821-1827. [CrossRef]

7. Park, J.H.; Kim, K.H.; Cho, J.M.; Lim, S.K. Fabrication of beta- and beta"- $\mathrm{Al}_{2} \mathrm{O}_{3}$ tubes by pressureless powder packing forming and salt infiltration. J. Mater. Sci. 1998, 33, 5695-5702. [CrossRef]

8. Lu, X.; Xia, G.-G.; Lemmon, J.P.; Yang, Z. Advanced materials for sodium-beta alumina batteries: Status, challenges and perspectives. J. Power Sources 2010, 195, 2431-2442. [CrossRef]

9. Hodge, J.D. Kinetics of the $\beta^{\prime \prime}$-to- $\beta$ Transformation in the System $\mathrm{Na}_{2} \mathrm{O}-\mathrm{Al}_{2} \mathrm{O}_{3}$. J. Am. Ceram. Soc. 1983, 66, 166-169. [CrossRef]

10. Park, J.-H.; Kim, K.-H.; Lim, S.-K. Influence of stabilizers on $\mathrm{Na}-\beta^{\prime \prime}-\mathrm{Al}_{2} \mathrm{O}_{3}$ phase formation in $\mathrm{Li}_{2} \mathrm{O}(\mathrm{MgO})-\mathrm{Na}_{2} \mathrm{O}-\mathrm{Al}_{2} \mathrm{O}_{3}$ ternary systems. J. Mater. Sci. 1998, 33, 5671-5675. [CrossRef]

11. De Jonghe, L.C. Grain boundaries and ionic conduction in sodium beta alumina. J. Mater. Sci. 1979, 14, 33-48. [CrossRef]

12. Heinz, M.V.; Graeber, G.; Landmann, D.; Battaglia, C. Pressure management and cell design in solid-electrolyte batteries, at the example of a sodium-nickel chloride battery. J. Power Sources 2020, 465, 228268. [CrossRef]

13. Dirksen, C.L.; Skadell, K.; Schulz, M.; Stelter, M. Effects of $\mathrm{TiO}_{2}$ doping on $\mathrm{Li}^{+}$-stabilized Na- $\beta^{\prime \prime}$-alumina for energy storage applications. Sep. Purif. Technol. 2019, 213, 88-92. [CrossRef]

14. Sudworth, J.L. The sodium/sulphur battery. J. Power Sources 1984, 11, 143-154. [CrossRef]

15. Sudworth, J.L.; Barrow, P.; Dong, W.; Dunn, B.; Farrington, G.C.; Thomas, J.O. Toward Commercialization of the Beta-Alumina Family of Ionic Conductors. MRS Bull. 2000, 25, 22-26. [CrossRef]

16. Sudworth, J.L.; Tilley, A.R. The Sodium Sulfur Battery; Chapman and Hall: London, UK, 1985; ISBN 0-412-16490-6.

17. Sheng, Y.; Nicholson, P.S. Microstructural development of a $\mathrm{ZrO}_{2}-\mathrm{NaB}^{\prime \prime}-\mathrm{Al}_{2} \mathrm{O}_{3}$ composite. J. Mater. Sci. 1988, 982-986. [CrossRef]

18. Yi, E.; Temeche, E.; Laine, R.M. Superionically conducting $\beta^{\prime \prime}-\mathrm{Al}_{2} \mathrm{O}_{3}$ thin films processed using flame synthesized nanopowders. J. Mater. Chem. A 2018, 6, 12411-12419. [CrossRef]

19. Moghadam, H.A.; Paydar, M.H. The Effect of Nano CuO as Sintering Aid on Phase Formation, Microstructure and Properties of Li2O-Stabilized b"-Alumina Ceramics. J. Ceram. Sci. Tech. 2016, 441-446. [CrossRef]

20. Zhu, C.; Hong, Y.; Huang, P. Synthesis and characterization of $\mathrm{NiO}$ doped beta- $\mathrm{Al}_{2} \mathrm{O}_{3}$ solid electrolyte. J. Alloy. Compd. 2016, 688, 746-751. [CrossRef]

21. Wei, X.; Cao, Y.; Lu, L.; Yang, H.; Shen, X. Synthesis and characterization of titanium doped sodium beta"-alumina. J. Alloy. Compd. 2011, 509, 6222-6226. [CrossRef]

22. Shi, J.; Hong, Y.; Zhu, C. Effect of Chromium on Electrochemical and Mechanical Properties of Beta- $\mathrm{Al}_{2} \mathrm{O}_{3} \mathrm{Solid}_{\text {Electrolyte }}$ Synthesized Via a Citrate-Nitrate Combustion Method. Crystals 2020, 10, 987. [CrossRef]

23. Yang, L.-P.; Shan, S.; Wei, X.; Liu, X.; Yang, H.; Shen, X. The mechanical and electrical properties of $\mathrm{ZrO}_{2}-\mathrm{TiO}_{2}-\mathrm{Na}^{-} \beta / \beta^{\prime \prime}$-alumina composite electrolyte synthesized via a citrate sol-gel method. Ceram. Int. 2014, 40, 9055-9060. [CrossRef]

24. Chen, G.; Lu, J.; Li, L.; Chen, L.; Jiang, X. Microstructure control and properties of $\beta^{\prime \prime}-\mathrm{Al}_{2} \mathrm{O}_{3}$ solid electrolyte. J. Alloy. Compd. 2016, 673, 295-301. [CrossRef]

25. Kennedy, J.H.; Akridge, J.R.; Kleitz, M. Complex plane analysis of the impedance and admittance of polycrystalline sodium- $\beta$ alumina doped with transition metal ions. Electrochim. Acta 1979, 24, 781-787. [CrossRef]

26. Wasiucionek, M. Electrical properties of $\mathrm{CoO}, \mathrm{NiO}, \mathrm{CuO}$ and $\mathrm{ZnO}$ doped beta"-alumina. Solid State Ion. 1982, 7, 283-286. [CrossRef]

27. Lu, X.; Li, G.; Kim, J.Y.; Meinhardt, K.D.; Sprenkle, V.L. Enhanced sintering of $\beta^{\prime \prime}-\mathrm{Al}_{2} \mathrm{O}_{3} / \mathrm{YSZ}$ with the sintering aids of TiO2 and MnO2. J. Power Sources 2015, 295, 167-174. [CrossRef]

28. Erkalfa, H.; Misirli, Z.; Baykara, T. The effect of $\mathrm{TiO} 2$ and $\mathrm{MnO} 2$ on densification and microstructural development of alumina. Ceram. Int. 1998, 24, 81-90. [CrossRef]

29. BAGLEY, R.D.; CUTLER, I.B.; Johnson, D.L. Effect of TiO2 on Initial Sintering of $\mathrm{Al}_{2} \mathrm{O}_{3}$. J. Am. Ceram. Soc. 1970, 53, 136-141. [CrossRef]

30. Bay, M.-C.; Heinz, M.V.F.; Figi, R.; Schreiner, C.; Basso, D.; Zanon, N.; Vogt, U.F.; Battaglia, C. Impact of Liquid Phase Formation on Microstructure and Conductivity of Li-Stabilized Na- $\beta^{\prime \prime}$-alumina Ceramics. ACS Appl. Energy Mater. 2019, 2, 687-693. [CrossRef]

31. Li, H.; Fan, H.; Zhang, J.; Wen, Y.; Chen, G.; Zhu, Y.; Lu, J.; Jiang, X.; Hu, B.; Ning, L. Sintering behavior and properties of lithium stabilized sodium $\beta^{\prime \prime}$-alumina ceramics with YSZ addition. Ceram. Int. 2019, 45, 6744-6752. [CrossRef] 
32. Lee, S.-T.; Lee, D.-H.; Kim, J.-S.; Lim, S.-K. Influence of Fe and Ti addition on properties of $\mathrm{Na}^{+}-\beta / \beta^{\prime \prime}$-alumina solid electrolytes. Met. Mater. Int. 2017, 23, 246-253. [CrossRef]

33. Boilot, J.P.; Théry, J. Influence de l'addition d'ions etrangers sur la stabilite relative et la conductivite electrique des phases de type alumine $\beta$ et $\beta^{\prime \prime}$. Mater. Res. Bull. 1976,11,407-413. [CrossRef]

34. Hodge, J.D. Phase Relations in the System $\mathrm{Na}_{2} \mathrm{O}-\mathrm{Li}_{2} \mathrm{O}-\mathrm{Al}_{2} \mathrm{O}_{3}$. J. Am. Ceram. Soc. 1984, 67, 183-185. [CrossRef]

35. Morgan, P.E.D.; Koutsoutis, M.S. Phase Studies Concerning Sintering in Aluminas Doped with Tiं ${ }^{4+}$. J. Am. Ceram. Soc. 1985, 68, C-156. [CrossRef]

36. Boilot, J.P.; Kahn, A.; Thery, J.; Collongues, R.; Antoine, J.; Vivien, D.; Chevrette, C.; Gourier, D. Influence of foreign ions addition on relative stability and electrical conductivity of $\beta$ and $\beta^{\prime \prime}$ alumina type phases localization of impurities. Electrochim. Acta 1977, 22, 741-745. [CrossRef]

37. van Zyl, A.; Thackeray, M.M.; Duncan, G.K.; Kingon, A.I.; Heckroodt, R.O. The synthesis of beta alumina from aluminium hydroxide and oxyhydroxide precursors. Mater. Res. Bull. 1993, 28, 145-157. [CrossRef]

38. Heinz, M.V.; Bay, M.-C.; Vogt, U.F.; Battaglia, C. Grain size effects on activation energy and conductivity: Na- $\beta$ "-alumina ceramics and ion conductors with highly resistive grain boundary phases. Acta Mater. 2021, 213, 116940. [CrossRef]

39. Cooper, S.J.; Bertei, A.; Finegan, D.P.; Brandon, N.P. Simulated impedance of diffusion in porous media. Electrochim. Acta 2017, 251, 681-689. [CrossRef] [PubMed]

40. Zhang, Y.; Chen, Y.; Chen, F. In-situ quantification of solid oxide fuel cell electrode microstructure by electrochemical impedance spectroscopy. J. Power Sources 2015, 277, 277-285. [CrossRef] 